Federal Reserve Bank of Dallas

Globalization and Monetary Policy Institute

Working Paper No. 71

http://www.dallasfed.org/assets/documents/institute/wpapers/2011/0071.pdf

\title{
Vertical Specialization, Intermediate Tariffs, and the Pattern of Trade: Assessing the Role of Tariff Liberalization to U.S. Bilateral Trade 1989-2001*
}

\author{
Shalah Mostashari \\ University of Texas at Austin
}

January 2011

\begin{abstract}
How important are intermediate tariffs in determining trade patterns? Empirical work measuring the impact of tariff liberalization most commonly focuses on the effects of barriers imposed by importers, but exporter trade policy should also matter when exports are produced with imported intermediates. Guided by extensions of the Eaton and Kortum (2002) model, I study the impact of trade liberalizations on U.S. bilateral trade from 19892001. I estimate the impact on U.S. bilateral trade flows of both intermediate tariffs imposed by countries exporting to the United States and U.S. tariffs. My empirical estimates suggest that, especially for less developed countries, their own liberalizations have been quantitatively much more important in explaining changes in bilateral trade patterns, on average 4.2 times larger than the impact of US liberalizations. For the entire sample of countries, countries' own liberalizations have been 2.2 times more important.
\end{abstract}

JEL codes: F1

\footnotetext{
* Shalah Mostashari, University of Texas at Austin, BRB 1.116, Mailcode C3100, Austin, TX 78712. 512-471-3211. mostasha@eco.utexas.edu. I thank Peter Debaere, Dean Corbae, Kripa Freitas, Jason Abrevaya and Mark Wynne for helpful comments, and Allesandro Nicita for help with the data. All remaining errors are my own. The views in this paper are those of the author and do not necessarily reflect the views of the Federal Reserve Bank of Dallas or the Federal Reserve System.
} 


\section{Introduction}

In this paper I examine whether a country’s own trade policy is an important source of comparative advantage. The channel I consider builds on the insight that countries which are not competitive at producing intermediate goods themselves may still be able to competitively produce more advanced stages of a good when able to acquire imported intermediate goods cheaply. In other words, when trade is vertically specialized, meaning that exported goods are made with imported intermediates as first defined by Hummels, Rapoport, and Yi (1998), more liberal trade policy results in cheaper imported intermediates and a more likely comparative advantage.

I test this hypothesis by studying the pattern of U.S. trade between 1989 and 2001. One striking feature of the data is that during this period, almost half of the increase in real U.S. manufacturing imports came from less developed countries, and the growth rates of their exports are substantially larger than those of developed countries. ${ }^{1}$ While tariffs are generally thought to play a key role in explaining trade growth, U.S. tariff policy alone cannot explain either the changing distribution of import shares among countries, or the magnified growth of less developed country trade. Yet under vertical specialization, tariff policies of exporting countries have a significant impact on specialization patterns by increasing or decreasing the costs of foreign intermediates.

\footnotetext{
${ }^{1}$ Using the Bureau of Labor Statistics Import Price Indexes to calculate real U.S. imports, those countries with 1989 Real GDP per capita (constant 2005 dollars) less than 10,000 dollars accounted for 49 percent of the net change in real U.S. imports between 1989 and 2001. China’s and Mexico’s shares of the net change in real trade were each around 17 percent.
} 
Notwithstanding the documented growth of this type of trade, further evidence of vertical specialization as a possible contender in explaining these trade patterns is implied by the very suggestive way trade policy has evolved across countries over the period 1989 to $2001 .^{2}$ The least developed countries, which experienced the greatest growth rates in exports to the U.S., also experienced the greatest degree of trade liberalization.

Identifying why less developed country export growth has outpaced developed country export growth may be incorporated into the broader question of what explains trade growth. Economists have long seen increases in real trade as being the consequence of multilateral and bilateral trade liberalizations and to technology led declines in transportation costs. Monopolistic Competition or 'New Trade Theory' models, such as Helpman (1987) and Hummels and Levinsohn (1995), can explain trade growth among developed countries through income convergence. ${ }^{3}$ In recent years, empirical research

\footnotetext{
${ }^{2}$ Several empirical studies have documented the growing importance of vertical production networks and their contribution to trade growth. Hummels, Rapoport, and Yi (1998) show that vertical specialization, as measured by the value of imported intermediates in exports, or foreign value added in exports, has accounted for a large and increasing share of international trade over the last several decades. Using inputoutput tables for 10 OECD countries and four emerging markets, Hummels, Ishii, and Yi (2001) calculate that vertical specialization accounts for 21 percent of these countries' exports and grew almost 30 percent between 1970 and 1990. They also show that vertical specialization accounts for 30 percent of the growth in these countries' exports. In related work, Feenstra (1998) compares several different measures of the international fragmentation of production, and argues that all have increased since the 1970's.

${ }^{3}$ Debaere (2003) shows that the increasing similarity in GDP among OECD country pairs leads to higher bilateral trade to GDP ratios, suggesting some support for Helpman (1987), whose model explains intraindustry trade that is prevalent among developed countries. However, he also shows that Helpman's
} 
has focused on the changing ranges of goods that countries export, and have observed non-negligible increases in this range among countries undergoing trade liberalizations. This finding has led some to conjecture that trade in new goods is behind the magnified growth in world trade. ${ }^{4}$ Finally, increases in outsourcing and vertical production networks have likewise been put forth as an explanation. Yi (2003) was one of the first to argue that vertical specialization was what was needed to solve the quantitative puzzle of why aggregate trade responds so strongly to moderate tariff reductions. As Yi (2003)

prediction is rejected for non-OECD countries, among which intra-industry trade is not critical. Baier and Bergstrand (2001) estimate a gravity equation of bilateral trade derived from a standard trade model. They find that average bilateral tariff rate reductions account for about 25 percent of trade growth in their sample of several OECD countries, but little evidence of income convergence playing a role in explaining trade growth.

${ }^{4}$ Ruhl (2005) shows how permanent tariff reductions, as opposed to temporary business cycle shocks, affect firms' decisions to export such that the failure to account for these new goods produces large aggregate elasticities of exports to tariffs. Kehoe and Ruhl (2003) study trade liberalizations for 18 countries and show how substantial increases in the extensive margin coincided with trade liberalizations. However, recent research has undermined the claim that the extensive margin is behind the magnified response of trade to tariffs. Debaere and Mostashari (2010) investigate the link between the extent of tariff reductions and the changing extensive margin using disaggregate trade and tariff data for the United States. They find that U.S. tariffs and tariff preferences are statistically significant, but their overall contribution to the extensive margin is small. These findings of a limited response to tariffs specifically along the extensive margin of trade can also be linked to recent plant-level studies. Bernard and Jensen (2004a,b) and Das, Roberts and Tybout (2007) find that there are large fixed costs for firms that begin to export. These fixed costs rationalize why moderate tariff reductions primarily induce an increase in exports at the intensive rather than the extensive margin. 
points out, in order to explain actual trade increases standard trade models require trade to tariff elasticities much higher than those typically estimated or employed in simulations and calibrations. ${ }^{5}$ By simulating global tariff reductions, he shows that his two-country model of vertical specialization can generate a nonlinear response of trade to tariff reductions and can explain over 50 percent of the growth of world trade over his sample period without assuming counterfactually large elasticities.

Yi's (2003) two-country analysis focuses on the developed world: the United States and the rest of the developed world. This paper exploits the variation in tariff policy across countries. In evaluating the response of U.S. imports relative to output by country to U.S. tariff liberalizations, one finds that the countries with the largest increases in exports to the United States relative to U.S. trade liberalizations correspond to those country groups which underwent substantial liberalizations in their own tariff regimes. This finding is a direct consequence of the greater export growth rates of low income countries and the fact that the evolution of U.S. tariff policy did not differ systematically

\footnotetext{
${ }^{5}$ For example, Yi measures developed world tariff decreases for manufactured goods between 1962 and 1999 to be around 11 percentage points, and indicates that if tariff reductions are to explain the observed growth in trade's share of output, standard trade models require elasticities of substitution in the order of 12-15. Anderson et al. (2005), argue that only an elasticity of 17 can match world bilateral trade patterns, and Feinberg and Keane (2009) need an elasticity in the range of 25 to 30 to explain the increase of intrafirm trade as a fraction of total sales for Canadian Multinationals between 1983 and 1996. However, actual estimates of these elasticities are much smaller. For example, Broda and Weinstein's (2006) median estimate of the elasticity of substitution is in the order of 3.1; Romalis's (2007) demand elasticities range between 6.2 and 10.9 .
} 
across developed and less developed country lines. ${ }^{6}$ Hence, the same anomaly which motivates Yi's (2003) analysis is present here, but more pronounced for those countries which underwent a large degree of trade liberalization themselves over the sample period.

In order to empirically investigate whether trade and tariff policy patterns are related under the auspices of vertical specialization, an economic model which recognizes intermediate trade is required. Eaton and Kortum (2002) develop a multi-country and multi-good Ricardian model that captures the competing forces of productivity differences and geographic barriers in determining trade flows. Furthermore, their model explicitly allows for access to intermediate goods to contribute to specialization patterns. This paper extends their model to the industry level and looks at trade volumes over the period 1989-2001 to exploit the variation in bilateral trade and trade policy across countries, industries, and time. I show that a simple modification of one of Eaton and Kortum's (2002) key equations produces a measure of bilateral trade that is directly dependent on both importing country tariffs and exporting country tariffs. Importantly, this paper makes a first attempt to present an empirical trade model which satisfies several criteria; the model first incorporates the possibility of vertically specialized trade, second is general in its ability to be applied to many specialization patterns, third allows

\footnotetext{
${ }^{6}$ U.S. tariffs did decrease more for NAFTA countries and also for countries which gained eligibility for GSP status over the sample period. However, for most other countries U.S. tariff decreases were in the order of 2 percentage points on average.
} 
one to quantify the response of trade to both final and intermediate tariff liberalizations, and fourth is derived directly from theory. ${ }^{7}$

Consistent with what the stylized facts suggest, the estimation results suggest that exporting country tariffs are statistically significant and that their liberalizations have been, on average, relatively more important in increasing bilateral integration with the United States than U.S. liberalizations. The liberalizations of the least developed countries in the sample, those countries with 1989 Real GDP per capita (constant 2005 dollars) less than 3000 dollars, have on average been 4.2 times more important in explaining changes in bilateral trade patterns than U.S. tariff liberalizations.

Though there is a growing body of research documenting the importance of international production networks, little is known about the cause of this type of production and the contribution of tariff policy. ${ }^{8}$ Certainly there is a sizeable literature, both empirical and computational, quantifying the response of trade to tariff liberalizations and changes in production costs in general, but little attention has been

\footnotetext{
${ }^{7}$ Anderson and van Wincoop (2003) have been especially critical of the misleading and biased results of gravity model estimations not founded in theory.

${ }^{8}$ A large literature on outsourcing's role on rising wage inequality in advanced nation has emerged in response to these changing trade patterns. See, for example, Feenstra and Hanson (1996a,b) and Markusen and Venables (1995, 1996a,b) who show how outsourcing can augment the wage skill gap in both locations. Krugman and Venables (1995) find that lowering transport costs can lead to a fall in wage inequality across regions. More recently, Feenstra and Hanson (1999) decompose the effects of outsourcing and skill-biased technological change on wages for the United States between 1972 and 1990. Hsieh and Woo (2003) look at the impact of outsourcing to China on Hong-Kong’s Labor Market.
} 
given to quantifying the impact of intermediate tariff liberalization to export growth. ${ }^{9} \mathrm{~A}$ few papers which are similar in spirit to the analysis performed here and which find consistent results are Feinberg and Keane (2001), Swenson (2004), and Feenstra and Kee (2007). Feinberg and Keane (2001) examine how bilateral trade flows of U.S. multinational corporations and their Canadian affiliates responded to U.S. and Canadian tariff reductions. They find that Canadian affiliate sales to the United States are negatively correlated with Canadian tariffs. Swenson (2004) examines how outsourcing decisions are affected by changes in country and competitor production costs, by looking exclusively at offshore assembly program (OAP) exports to the US, and likewise allows for intermediate trade costs to influence production costs. Swenson (2004) finds that when a country's costs rise or competitors' costs fall, the share of U.S. OAP activities in that location decline. Feenstra and Kee (2007) measure the response of an index of export variety (of Mexico’s exports to the US) to U.S. tariffs under NAFTA as well as Mexcio’s tariffs under NAFTA. They find that both have a statistically significant negative influence on Mexico’s export variety.

\footnotetext{
${ }^{9}$ Computable General Equilibrium (CGE) models have been used extensively to simulate the economic effects of bilateral and multilateral trade liberalizations. See Deardorff and Stern (1990), Brown, Deardorff and Stern (1995), Kehoe and Kehoe (1995), and Whalley (1985). For a survey of the literature on PTA’s, see Baldwin and Venables (1995). Romalis (2007) and Clausing (2001) look specifically at the effects of NAFTA and CUSFTA using disaggregate trade and tariff data. In an aggregate study, Baier and Bergstrand (2001) estimate a gravity equation of bilateral trade derived from a standard trade model. More recently Yi (2010) extended the Eaton and Kortum (2002) model to explain how vertical specialization can help explain the home bias in trade.
} 
The remainder of this paper is organized as follows. Section 2 provides summary statistics of tariff and trade patterns for the United States and other countries during the sample period. Section 3 presents the main theory regarding the role of intermediate and final goods tariffs and other cost variables in explaining trade patterns. Sections 4 and 5 contain the empirical strategy and results. Section 6 concludes.

\section{Descriptive Statistics}

The purpose of this paper is to investigate and quantify the importance of tariff policy under vertical specialization. In this context, tariff reductions can affect trade patterns on two fronts. First, countries which allow freer trade for intermediates and capital goods can decrease the cost of domestic production of final goods that make use of foreign intermediates. Clearly, the impact of a country's own tariff policy will be particularly relevant to export penetration under vertical specialization. That is, if goods were not produced with imported intermediates either before or after a decrease on tariffs, then the impact of tariff liberalizations on export growth should be less significant. ${ }^{10}$ Second, as is the case even when trade is not vertically specialized, preferential tariffs can

\footnotetext{
${ }^{10}$ In addition to vertical specialization, trade policy of exporting countries may influence specialization patterns through other means. For example, several researchers have argued the importance of trade in general and particularly of capital goods or other intermediates which have a higher content of technology as a source of technology diffusion. See, for example, Xu and Wang (1999) and references therein. Coe and Helpman (1995) relate productivity to the import-share weighted R\&D of the countries’ trade partners, and find a positive regression coefficient.
} 
divert trade away from possibly more efficient sources if rates are sufficiently lower for preferentially treated countries.

The objective of this section is to characterize the main stylized facts of U.S. imports, U.S. tariffs and world tariff trends between 1989 and 2001. To do so, I first investigate whether or not U.S. imports as a share of output have grown by a large amount relative to U.S. tariff liberalization. Indeed, if one looks at the growth of trade to output relative to decreases in U.S. tariffs, there is a great deal of variation across countries. In fact, less developed countries are accounting for an ever increasing share of U.S. trade, and constitute a non-trivial source of U.S. import growth. Historically, these countries have been the most protected, and consequently are the countries with room for the most substantial liberalizations. Upon examination, those countries which experienced the greatest growth rates in exports to the United States also underwent the most pronounced liberalizations. This finding is consistent with the conjecture that increased access to foreign intermediate goods by way of a country's own trade liberalization is an important determinant of export growth.

\subsection{Sources of U.S. import growth}

Data on U.S. bilateral trade flows for manufacturing goods and tariff data (except for the United States) are taken from the World Bank’s Trade and Production Database, 1976-2004. ${ }^{11}$ GDP data are taken from the Penn World Tables V.6.3. U.S. tariff data are taken from the United States Trade Commission’s Tariff Database.

\footnotetext{
11 The sample is limited to 2001 since necessary U.S. data do not go beyond this year.
} 
In the descriptive statistics that follow, the paper first looks at the change in U.S. manufacturing imports relative to U.S. output over the sample period. For this, imports are limited to those coming from a consistent panel of countries. In other words, all countries that were restructured (e.g. USSR) or for which the United States had a trade embargo in any year during the sample period are eliminated. ${ }^{12}$ Since trade patterns will be linked to bilateral trade policies, the set of countries is further limited only to countries for which these data are available. The countries included in the trade statistics are listed in Table 1.

I first investigate whether or not U.S. imports exhibit the same quantitative anomaly characteristic of the post WWII world economy, by looking at the changes in U.S. manufacturing imports relative to U.S. output between 1989 and 2001. ${ }^{13}$ Table 2 shows the evolution of the total U.S. imports relative to U.S. output and U.S. average manufacturing tariffs for the sample. The change in the natural log of the import share of output was approximately 58 percent, from .148 in 1989 to .265 in 2001. However, import weighted U.S. manufacturing tariffs decreased from 5.2 to 3.4 percent, which constitutes a decrease in the natural log of gross tariffs of approximately 2 percent. Generating this increase in trade from U.S. tariff reduction alone requires an elasticity of

\footnotetext{
${ }^{12}$ There is one exception. For Germany, trade data are summed for East and West Germany before unification.

${ }^{13}$ The focus of imports relative to output as a measure of trade growth is primarily because this is the measure for which Yi (2003) derives his magnified and non-linear effects for world tariff liberalization.
} 
the import share of output to gross tariffs of around -33.75 which is large relative to those typically found in CGE models and those found in the empirical literature. ${ }^{14}$

However, the growth rates in U.S. imports of different countries have been quite varied. There has been a steady increase in the share of U.S. imports from the least developed countries in the sample, while the share of U.S. imports from the richest countries experienced a steady decrease. In 1989, the countries with less than 10,000 dollars in real GDP per capita (measured in constant PPP 2005 dollars) accounted for approximately 11.6 percent of U.S. imports; however, by 2001, their share had doubled to 23.2 percent. In contrast, high income countries, those with more than 18,000 dollars in real GDP per capita (measured in constant PPP 2005 dollars) experienced a 15.3 percentage point decrease in their import shares.

If one compares changes in imports relative to U.S. output for particular countries and country groups to U.S. tariffs for these groups, one again finds a great deal of variation across countries. Table 3 summarizes the changes of the natural logs of imports relative to U.S. output, U.S. tariffs and the resulting implied trade to tariff elasticities for Canada, Mexico, China, and the rest of the world divided by development level between 1989 and 2001. The elasticities are highest for China and other low income countries. While Canada experienced a pronounced increase in trade, of 49 percent, it also enjoyed

\footnotetext{
${ }^{14}$ Elasticities found in the CGE literature are typically in the order of -2 to -3.5 . See Deardorff and Stern (1990) and Whalley (1985). In a gravity model of bilateral trade, Baier and Bergstrand (2001) estimate an elasticity of -6.43. Eaton and Kortum's (2002) estimated elasticity of their geographic barriers ranges from -2.4 to -12.86 depending on the specification.
} 
the largest decrease in average U.S. tariffs, around 4.1 percentage points. Consequently, the elasticity is only -11.84 . Mexico's elasticity, on the other hand, is a high -54.02 . Imports from China relative to U.S. output, grew by 212 percent. Therefore, China's implied trade to tariff elasticity is extraordinarily high at almost -266.64. However, even if one excludes China and Mexico, one finds that the least developed countries still have the largest growth rates producing elasticities of -133.68 and -138.9 for the two lowest income groups. For the high income countries, excluding Canada, the elasticity is -32.8. The substantial variation in the implied responses of trade to tariff reduction suggests that factors other than U.S. tariffs are contributing to the increased penetration of developing country trade. Furthermore, because U.S. tariffs did not decrease very much over this time period, on average around 2 percent, elasticities needed for U.S. tariff policy alone to generate these responses of trade are too large relative to what traditional models would suggest.

\subsection{Trade liberalizations across countries 1989-2001}

To link these findings to the implications of tariff policy under vertical specialization, trends in tariff rates across all sampled countries are considered. Table 4 summarizes average annual tariffs across countries and country groups. The particular measure of tariffs used for all countries except Mexico and Canada is the import weighted MFN tariff averaged across countries and ISIC 3-digit manufacturing industries. For Mexico and Canada, the tariff reported is the average manufacturing tariff imposed on U.S. products taking into consideration the Canada U.S. Free Trade 
Agreement (CUSFTA) and the North American Free Trade Agreements (NAFTA). The largest decrease comes from the least developed countries with a change in the natural log of gross average tariffs of 39 percent (from an average tariff of 76 percent in 1989 to 19 percent in 2001). Lower middle income countries experienced a decrease in the natural $\log$ of their gross tariff rates by 15 percent, while the decrease for upper middle income countries and high income countries was only 5 and 3 percent respectively. Tariff data for China is unavailable for the earlier years, but still between 1992 and 2001 the natural log of gross tariffs decreased by 22 percent. On average Canadian tariffs on U.S. goods decreased by nearly 7 percentage points while Mexican tariffs on U.S. goods decreased by 8.2 percent between 1991 and 1999 .

With the exception of the NAFTA countries, U.S. tariffs decreased moderately, with no systematic difference in the decrease for developed and developing countries. ${ }^{15}$ Moreover, the changes in these countries' trade shares are hard to explain by U.S. tariff policy alone. Importantly, the least developed countries which were also the countries with the largest tariff decreases, had the greatest increases in U.S. import shares. While there are many reasons why less developed nations might be gaining relative to developed nations, these findings are at least consistent with the hypothesis that access to intermediates that must be imported may be an important component in explaining

${ }^{15}$ Exceptions are some former Eastern European States which acquired eligibility for the U.S. Generalized System of Preferences (GSP) tariff rates after losing their communist status. For these low income countries, one sees a larger decrease in U.S. tariff rates over the time period. See U.S. GSP Guidebook (1999) for the mandatory rules for eligibility. However, these outlier countries are not included in the sample. 
specialization patterns. If less developed countries are particularly disadvantaged at producing specialized intermediates, then tariff policy for these countries may be a critical determinant in expanding their exports.

\section{Theoretical Model}

The statistics above suggest that tariff policy of exporting countries may have important consequences for the determination of specialization patterns and also help explain why the least developed countries in 1989 have experienced greater growth rates in U.S. trade shares. In order to investigate this hypothesis, the paper extends and modifies the Eaton and Kortum (2002) model to formulate an empirical model that relates bilateral trade flows to both importing and exporting country tariffs.

Employing a probabilistic model of technological heterogeneity, Eaton and Kortum (2002) derive simple structural equations linking bilateral trade to parameters related to absolute advantage, comparative advantage and geographic barriers in a multicountry setting. Furthermore, their model explicitly incorporates a role for intermediate trade in the determination of specialization patterns. The Eaton and Kortum (2002) set-up is at the country level, yet both tariffs and intermediate intensity vary at more disaggregate levels. Therefore, the analysis first proposes a methodology which maintains the main structure of their theory, but which suggests an estimation that is at the industry 
level, and that therefore allows one to exploit the variation in the data at this less aggregate level. $^{16}$

Several important results for the derived empirical model are highlighted. First, the structural model developed here suggests a specific way of measuring bilateral trade when one wants to relate trade to bilateral tariffs when there is trade in intermediate goods and in a multi-country setting. Second, the particular measure of trade derived depends only on trade frictions between the two countries trading, and is independent of trade policies with other countries. Third, a simple manipulation of the trade flow term shows that the measure of vertical specialization first formulated by Hummels, Rapoport, and Yi (1998) and Hummels, Ishii, and Yi (2001), the value of imported intermediates in exports, is nested within the trade flow term as an extreme case.

\subsection{Technology and Preferences}

There are $\bar{K}$ sectors. $J$ and $K$ will be used to denote sectors and any parameter or variable that is sector specific. Goods belonging to a particular sector are indicated with lower cases, such that a good belonging to sector $K$ is denoted $k$ and a good belonging to sector $J$ is denoted $j$, where within each sector there are a continuum of goods $j, k \in[0,1]$. There are $\mathrm{N}$ countries, and $i, n$, and $s$ will be used to indicate different countries.

\footnotetext{
${ }^{16}$ Several studies have sought to extend the Eaton and Kortum (2002) model to the sector level. For example, see Chor (2009) and Donaldson (2008); however, these papers do not also include intermediate trade. Yi (2010) extends the model to include three stages of production, but maintains the aggregate specification.
} 
Consistent with Ricardian models, countries have access to the same technology but vary in their efficiency levels. This is captured by a country-good specific total factor productivity term $A_{i k}$. The cost of a bundle of inputs, which consist of labor and intermediate goods, is assumed to be the same for all goods within a particular sector within a country, but varies across sectors within a country. This is because within countries inputs are mobile across sectors, and goods within a sector employ factors with the same intensity; however, goods produced in different sectors vary in their intermediate and labor intensities. The cost of an input bundle of producing good $k$ in country $i$ as $c_{i K} \cdot{ }^{17}$

Geographic barriers take the convenient "iceberg" form, such that delivering a unit from country $i$ to country $n$, requires producing $d_{n i}>1$ units for $n \neq i$, and $d_{i i}=1$. The triangle inequality is assumed to hold (such that for any three countries, $i, n$, and $s$, $d_{n i} \leq d_{n s} d_{s i}$ ), as well as symmetry $d_{i n}=d_{n i}$. In addition to these geographic barriers, an industry specific ad valorem tariff may be imposed by the importing country. Therefore, the total trade cost for country $n$ to import a good $k$ from country $i$ is given by $\left(1+\tau_{n i K}\right) d_{n i}$.

Assuming that production of a particular variety is subject to perfect competition, the price a consumer in country $n$ faces for a good $k$ produced in country $i$ is

\footnotetext{
${ }^{17}$ This is one of the departures from Eaton and Kortum (2002) who assume that intermediate shares are the same across all goods. In general, the main extension of Eaton and Kortum's model is the added dimensionality of sector specific parameters.
} 
(1) $\quad p_{n i}(k)=\frac{c_{i K}\left(1+\tau_{n i K}\right) d_{n i}}{A_{i k}}$.

Consumers have preferences for all varieties within each industry, but are indifferent about where they purchase the good. Therefore, they choose to buy the cheapest good available such that the price actually paid for good $k$ by consumers in country $n$ is

$$
p_{n}(k)=\min \left\{p_{n i k} ; i=1 \ldots N\right\} .
$$

Facing these prices, buyers, who could be final consumers or firms buying intermediate inputs, purchase individual goods to maximize their respective objective functions. Specifically, consumers of final goods maximize

(3) $\quad U=\prod_{J=1}^{\bar{K}}\left(Q_{J}\right)^{B_{J}}$

where $B_{J}$ is the share of income spent on goods belonging to industry $J, \sum_{J=1}^{\bar{K}} B_{J}=1$, and where $Q_{J}$ is a composite industry specific good defined by the following CES function:

$$
Q_{J}=\left[\int_{0}^{1} q(j)^{(\sigma-1) / \sigma} d j\right]^{\sigma /(\sigma-1)}
$$

where $\sigma>0$ is the elasticity of substitution among varieties of goods within a sector and is assumed to be the same for all sectors. ${ }^{18}$ Note that the industry specific composite

\footnotetext{
${ }^{18}$ One could also assume that the elasticity of substitution is sector specific. Since the term is canceled out of the empirical model, the results are not dependent on this assumption.
} 
goods are non-traded. Assembly takes place by the consumer after purchasing the individual varieties from their cheapest sources.

Producers, use the $\bar{K}$ composite intermediate goods as well as labor in order to produce a final good. Specifically, for a producer of good $k$, in country $i$, the production function takes the form

$$
x_{i k}=A_{i k} L^{\alpha_{K L}} \prod_{J=1}^{\bar{K}}\left(Q_{J}\right)^{\alpha_{K J}}
$$

where $\alpha_{K L}+\sum_{J=1}^{\bar{K}} \alpha_{K J}=1$ and $Q_{J}$ is defined by equation (4). Here $\alpha_{K L}$ is the cost share of labor, $\alpha_{K J}$ is the cost share of composite intermediate $J$ in sector $K$ goods' production, and $L$ is the quantity of labor used. Given this specification, the cost of an input bundle used in the production of good $k$ in country $i$ can be expressed

(6) $\quad c_{i K}=\left(\frac{w_{i}}{\alpha_{K L}}\right)^{\alpha_{K L}} \prod_{J=1}^{\bar{K}}\left(\frac{p_{i J}}{\alpha_{K J}}\right)^{\alpha_{K J}}$

where $p_{i J}$ is the price index for composite good $J$ for country $i$.

\subsection{Productivity and Trade Flows}

Following Eaton and Kortum (2002), a probabilistic representation of technological efficiency is modeled. Assume that country i's efficiency in producing good $k$ is the realization of a random variable $A_{i k}$ (drawn independently for each variety) from its country and industry specific probability distribution $F_{i K}(a)=\operatorname{Pr}\left[A_{i k} \leq a\right]$ which is Fréchet (Type II extreme value): 


$$
F_{i K}(a)=e^{-T_{i K} a^{-\theta}}
$$

where $T_{i K}>0$ and $\theta>1 .{ }^{19}$ As Eaton and Kortum (2002) point out, $T_{i K}$ governs the location of the distribution, with higher values indicating that a high efficiency draw is more likely. The parameter $\theta$ reflects the amount of variation within the distribution, with higher values reflecting less variability. Moreover, small values of $\theta$, indicating more heterogeneity, imply that relatively higher productivity levels exert a stronger force for trade against the resistance imposed by trade barriers. In other words, for small values of $\theta$, changes of trade costs result in relatively small changes in trade patterns, which are determined primarily by the state of technology $T_{i K}$.

\subsection{Prices}

The following derivations of price distributions follow those of Eaton and Kortum's (2002) with the only modification being to add the industry dimension to the analysis.

\footnotetext{
${ }^{19}$ Essentially this formulation allows for within sector and across sector heterogeneity within a country which has been a common feature in the literature on trade with heterogeneous firms such as Melitz (2003). Also as Donaldson (2010) notes, it is common to assume that productivities are drawn independently across varieties, industries, and countries (e.g. Melitz and Ottaviano (2008), Chaney (2008), and Helpman, Melitz, and Rubinstein (2008).
} 
Given the assumptions on technology and preferences, it is possible to derive an expression for the distribution of prices that country $i$ offers to country $n$ in each industry. For example for industry $K$ goods, the distribution of prices offered by $i$ to country $n$ is $\operatorname{Pr}\left[p_{n i k} \leq p\right]=1-F\left(\frac{c_{i K}\left(1+\tau_{n i k}\right) d_{n i}}{p}\right)$ or

$$
G_{n i K}(p)=1-e^{-\left[T_{i K}\left(c_{i K}\left(1+\tau_{n i K}\right) d_{n i}\right)^{-\theta}\right] p^{\theta}} .
$$

The lowest price for a good $k$ in country $n$ will be less than $p$ unless each source's price is greater than $p$. Hence the distribution of prices $G_{n K}(p)=\operatorname{Pr}\left[P_{n k} \leq p\right]$ for what country $n$ actually pays for industry $K$ goods is given by

$$
G_{n K}(p)=1-\prod_{i=1}^{N}\left[1-G_{n i K}(p)\right]=1-e^{-\Phi_{n K} p^{\theta}}
$$

where $\Phi_{n K}=\sum_{s} T_{s K}\left(c_{s K}\left(1+\tau_{n s K}\right) d_{n s}\right)^{-\theta}$.

Given these results, Eaton and Kortum (2002) derive three properties of the price distributions. The analogous properties taking into consideration the additional dimensionality are presented here. The first property is that the probability that country $i$ provides a good in industry $K$ at the lowest price to country $n$, is given by

$$
\Pi_{n i K}=\frac{T_{i K}\left(c_{i K}\left(1+\tau_{n i K}\right) d_{n i}\right)^{-\theta}}{\Phi_{n K}} \cdot{ }^{20}
$$

$$
\begin{aligned}
& \text { Analogous to Eaton and Kortum (2002), this is true since } \\
& \Pi_{n i K}=\operatorname{Pr}\left[p_{n i}(k) \leq \min \left\{p_{n s}(k) ; s \neq i\right\}\right]=\int_{0}^{\infty} \prod_{s \neq i}\left[1-G_{n s K}(p)\right] d G_{n i K}(p)=\frac{T_{i K}\left(c_{i K}\left(1+\tau_{n i K}\right) d_{n i}\right)^{-\theta}}{\Phi_{n K}}
\end{aligned}
$$


Second, the price of a good $k$ belonging to industry $K$ that country $n$ actually buys from any country $i$ also has the distribution $G_{n K}(p) .{ }^{21}$ Third, the exact price index for the CES objective function used by both final consumers and firms aggregating varieties to make an industry specific composite good is given by

$$
p_{n K}=\gamma \Phi_{n K}^{-1 / \theta}
$$

where $\gamma=\left[\Gamma\left(\frac{\theta+1-\sigma}{\theta}\right)\right]^{1 /(1-\sigma)}$ is the gamma function. ${ }^{22,23}$

\subsection{Trade Flows and Empirical Model}

One implication of the second property derived above is that n's average expenditure on an industry $K$ good purchased does not vary by source, since for goods that are purchased conditioning on the source has no bearing in the good's price.

${ }^{21}$ This is true since the distribution of prices of goods that $n$ actually buys from $i$ is given by $G_{n K}(p)=\frac{1}{\pi_{n i K}} \int_{0}^{p} \prod_{s \neq i}\left(1-G_{n s K}(q)\right) d G_{n i K}(q)$.

${ }^{22}$ Note that consumers and firms in a country have different expenditure shares on goods from a particular industry, but since their demand for individual varieties are derived form the same CES objective, they will share the same price index for that industry.

${ }^{23}$ The price index for the CES objective function (4) in country $n$ for industry $K$ is derived from the result that $p_{n K}=\left[\int_{0}^{1} p_{n k}^{1-\sigma} d k\right]^{1 /(1-\sigma)}=\left[\int_{0}^{\infty} p^{1-\sigma} d G_{n K}(p)\right]^{1 /(1-\sigma)}=\gamma \Phi_{n K}^{-1 / \theta}$. 
Therefore, the fraction of $n$ 's industry $K$ expenditures, spent on goods from country $i$ takes the same form as the probability that $i$ provides that good at least cost.

$$
\frac{X_{n i K}}{X_{n K}}=\frac{T_{i K}\left(c_{i K}\left(1+\tau_{n i K}\right) d_{n i}\right)^{-\theta}}{\Phi_{n K}} .
$$

where $\Phi_{n K}=\sum_{s} T_{s K}\left(c_{s K}\left(1+\tau_{n s K}\right) d_{n s}\right)^{-\theta} \cdot X_{n K}$ is $n$ 's total spending on industry $K$ goods, and $X_{n i K}$ is $n$ 's total spending on $K$ goods from country $i$. A similar expression can be derived for the share of $K$ sector expenditures that are produced by $n$.

$$
\frac{X_{n n K}}{X_{n K}}=\frac{T_{n K}\left(c_{n K}\right)^{-\theta}}{\Phi_{n K}}
$$

Dividing equation (12) by (13) gives an expression for the imports of sector $K$ goods emanating from country $i$, relative to $n$ 's expenditures on its own production.

$$
\frac{X_{n i K}}{X_{n n K}}=\frac{T_{i K}\left(c_{i K}\left(1+\tau_{n i K}\right) d_{n i}\right)^{-\theta}}{T_{n K}\left(c_{n K}\right)^{-\theta}}
$$

Given this price index defined in (11), one can derive an expression for the relative price index of sector $J$ composite goods for two countries:

$$
\frac{p_{i J}}{p_{n J}}=\left(\frac{\Phi_{i J}}{\Phi_{n J}}\right)^{-1 / \theta}
$$

An important implication of equation (15) is that if country $i$ systematically has higher trade barriers on $k$ goods from other countries relative to an otherwise identical country $n$, it would have a higher price index. Consequently, this would yield a relative cost disadvantage to $i$ in production of final goods that made intensive use of this industry. 
Moreover, the model shows that countries with systematically smaller trade barriers may become relatively more competitive in downstream goods.

By expression (12), one can write country i’s share of $n$ 's goods in consumption relative to $n$ 's share of its own goods in sector $J$ as

$$
\left(\frac{X_{i n J}}{X_{i J}}\right) /\left(\frac{X_{n n J}}{X_{n J}}\right)=\left(d_{i n}\left(1+\tau_{i n J}\right)\right)^{-\theta}\left(\frac{\Phi_{n J}}{\Phi_{i J}}\right) .
$$

Using (16), to substitute out the $\Phi_{i J} / \Phi_{n J}$ term from (15), the relative price index becomes a function of bilateral trade costs and i's share of $n$ 's goods in consumption relative to $n$ 's share of its own goods in sector $J$ :

$$
\frac{p_{i J}}{p_{n J}}=\left(\frac{\Phi_{i J}}{\Phi_{n J}}\right)^{-1 / \theta}=\left(d_{i n}\left(1+\tau_{i n J}\right)\right)\left[\left(\frac{X_{i n J}}{X_{i J}}\right) /\left(\frac{X_{n n J}}{X_{n J}}\right)\right]^{1 / \theta} .
$$

By (6), the relative cost of input bundles to produce a good $k$ is given by

$$
\frac{c_{i K}}{c_{n K}}=\left(\frac{w_{i}}{w_{n}}\right)^{\alpha_{K L}} \prod_{J=1}^{\bar{K}}\left(\frac{p_{i J}}{p_{n J}}\right)^{\alpha_{K J}}
$$

Finally, using equations (17) and (18), we can rewrite (14) as

$$
\frac{X_{n i K}}{X_{n n K}}=\left(\frac{T_{i K}}{T_{n K}}\right)\left(\frac{w_{i}}{w_{n}}\right)^{-\alpha_{K L} \theta}\left(\prod_{J=1}^{\bar{K}}\left\{\left(d_{i n}\left(1+\tau_{i n J}\right)\right)^{\theta}\left[\frac{X_{i n J} / X_{i J}}{X_{n n J} / X_{n J}}\right]\right\}^{-\alpha_{K J}}\right)\left(\left(1+\tau_{n i K}\right) d_{n i}\right)^{-\theta}
$$

Rearranging such that all trade volumes are on the left hand side, the equation becomes

$$
\frac{X_{n i K} \prod_{J=1}^{\bar{K}}\left[X_{i n J} / X_{i J}\right]^{\alpha_{K J}}}{X_{n n K} \prod_{J=1}^{\bar{K}}\left[X_{n n J} / X_{n J}\right]^{\alpha_{K J}}}=\left(\frac{T_{i K}}{T_{n K}}\right)\left(\frac{w_{i}}{w_{n}}\right)^{-\alpha_{K L} \theta}\left(\prod_{J=1}^{\bar{K}}\left\{\left(d_{i n}\left(1+\tau_{i n J}\right)\right)^{-\alpha_{K J} \theta}\right\}\right)\left(\left(1+\tau_{n i K}\right) d_{n i}\right)^{-\theta} .
$$


Before presenting the empirical methodology, it is worth taking a closer look at the individual components of equation (20). First, note that the denominator term on the left hand side serves to normalize trade flows from country $i$ with a comparable measure of $n$ 's consumption and use of its own goods. The numerator portion of the left hand side variable represents $n$ 's imports from country $i\left(X_{n i K}\right)$ multiplied by the weighted geometric mean of $n$ 's share of $i$ 's consumption ( raised to the total intermediate share in production of industry $K$ ) where the weights are the cost shares of each composite intermediate. The left hand side term increases when $n$ imports more from $i$, and when $i$ begins to spend a greater share of intermediate expenditures on goods from country $n$. Trade flows are related to relative productivities, relative wages, and relative trade costs. Specifically, the term $\prod_{J=1}^{\bar{K}}\left\{\left(d_{i n}\left(1+\tau_{i n J}\right)\right)^{\alpha_{K J}}\right\}$ captures the relative trade costs incurred by $i$ in using intermediates from $n$. The term $\left(1+\tau_{n i K}\right) d_{n i}$ captures $n$ 's additional trade costs of importing a good $k$ from $i$ relative to consuming the product from $n$.

I first consider how the trade flow measure on the left hand side relates specifically to measures of vertical specialization commonly used in the literature. To make this analogy, consider the simplified case without the added industry dimension. ${ }^{24}$ In this case equation (20) simplifies to

\footnotetext{
${ }^{24}$ The essential requirements to go from the disaggregate to the aggregate specification are that all industries within a country have the same trade costs, intermediate shares, and productivity distributions.
} 
(21) $\frac{X_{n i}}{X_{n n}}\left(\frac{X_{i n} / X_{i}}{X_{n n} / X_{n}}\right)^{1-\alpha_{L}}=\left(\frac{T_{i}}{T_{n}}\right)\left(\frac{w_{i}}{w_{n}}\right)^{-\alpha_{L} \theta}\left(\left(d_{i n}\left(1+\tau_{i n}\right)\right)^{-\left(1-\alpha_{L}\right) \theta}\right)\left(\left(1+\tau_{n i}\right) d_{n i}\right)^{-\theta}$

Notice that $X_{i n} / X_{i}$ represents the share of $i$ 's consumption that comes from country $n$.

Since consumers of final goods and firms demanding intermediate goods have the same preferences over varieties, the share of consumption by final consumers is also equal to the share of consumption of intermediates by firms. Therefore, the left hand side variable may also be written as

$$
\frac{X_{n i}}{X_{n n}}\left(\frac{X_{i n} / X_{i}}{X_{n n} / X_{n}}\right)^{1-\alpha_{L}}=\frac{X_{n i}}{X_{n n}}\left(\frac{\operatorname{INTER}_{\text {in }} /\left(1-\alpha_{L}\right) \text { OUTPUT }_{i}}{\text { INTER }_{n n} /\left(1-\alpha_{L}\right) \text { OUTPUT }_{n}}\right)^{1-\alpha_{L}}=\frac{X_{n i}}{X_{n n}}\left(\frac{\operatorname{INTER}_{\text {in }} / \text { OUTPUT }_{i}}{\text { INTER }_{n n} / \text { OUTPUT }_{n}}\right)^{1-\alpha_{L}}
$$

where INTER refers to the value of intermediate goods and OUTPUT refers to the value of output. The left hand side numerator,

(23) $X_{n i}\left(\text { INTER }_{\text {in }} / \text { OUTPUT }_{i}\right)^{1-\alpha}$

, bears some resemblance to the bilateral counterpart measure of vertical specialization defined by Hummels, Rapoport, and Yi (1998) and Hummels, Ishii, and Yi (2001): $V S=\operatorname{IMPORTS}_{n i}\left(\frac{\text { IMPORTED INTERMEDIATES }_{i n}}{\text { OUTPUT }_{i}}\right)$. When labor's share is 0 , equation (23) exactly equals VS. However, when labor's share is 1, the measure is simply equal to 
$n$ 's imports from $i$. Therefore, vertical specialization is nested within the trade flow term as an extreme case.

Another feature implied by the model is the magnified effect of bilateral trade liberalization when trade is vertically specialized. For example, assuming that tariffs and tariff changes are the same in both countries, i.e. $\tau_{\text {nit }}=\tau_{\text {int }}=\tau_{t}$, then $d \ln (\operatorname{lhs}) / d \ln (1+\tau)=-\theta\left(1+\left(1-\alpha_{L}\right)\right)$. The intermediate share of production intensifies the effect of bilateral tariff liberalizations. Moreover, liberalizations in industries with greater intermediate intensity will see a larger effect on trade flows.

Finally, the model suggests an exact measure of bilateral trade flows that is appropriate when measuring the response of trade liberalizations in a multi-country world where countries have different rates of tariff liberalization and different preferential agreements. The measure of bilateral trade flows developed is one that is independent of trade policy with other countries and only depends on the tariffs imposed by the two relevant countries. ${ }^{25}$ Moreover, the empirical equation does not require a multilateral trade resistance term as suggested by Anderson and van Wincoop (2003).

\section{Data and Empirical Strategy}

Taking the natural log of (20) produces the model to be estimated:

\footnotetext{
${ }^{25}$ The strategy employed in this paper was to come up with just such a measure. In Eaton and Kortum (2002), a similar strategy was employed to derive a bilateral trade flow measure that was independent of the exporting country’s trade barriers.
} 


$$
\ln \frac{\tilde{X}_{n i K}}{\widetilde{X}_{n n K}}=\ln \left(\frac{T_{i K}}{T_{n K}}\right)-\alpha_{K L} \theta \ln \left(\frac{w_{i}}{w_{n}}\right)-\theta \sum_{J=1}^{\bar{K}} \alpha_{K J} \ln \left(1+\tau_{i n J}\right)-\theta \ln \left(1+\tau_{n i K}\right)-\lambda \ln d_{i n}
$$

where $\ln \tilde{X}_{n i K}=\ln X_{n i K}+\sum_{J=1}^{\bar{K}} \alpha_{K J} \ln \left(X_{i n J} / X_{i J}\right)$, and $\lambda=\theta\left(2-\alpha_{K L}\right) \cdot{ }^{26}$ As can be seen from the above equation, bilateral trade flows depend on both the importing country and exporting country tariffs and geographic barriers, with the exporting country barriers becoming relatively more important in deterring bilateral vertically specialized trade the greater the intermediate share in production. This specification then allows one to estimate the main parameters of the model, as well as to quantify exactly how important the greater liberalizations experienced by the least developed countries has contributed to their greater growth rates in U.S. trade. In order to accomplish this, the model looks specifically at how tariffs on intermediate goods imposed by countries exporting to the U.S. as well as U.S. tariff preferences impact the degree of bilateral trade as measured by the left hand side variable. Therefore in estimating the specification suggested by equation (24), $n$ will represent the United States. Countries denoted by $i$ are all other trading partners with the United States for which all necessary data are available. The analysis includes data over the period 1989-2001 such that variables are also time specific.

\footnotetext{
${ }^{26}$ The derivation of this specification requires two important assumptions. First, factor cost shares within an industry are assumed to be the same across countries (i.e. that all countries share the same technology but only differ in productivity draws). Also required is the assumption that the parameter $\theta$, which governs the variation in the distribution of productivities, is the same across countries. This essentially requires that all countries' trade to tariff elasticities be the same regardless of development level.
} 
The left hand side variables are calculated using data from the World Bank's Trade and Production Database, 1976-2004. ${ }^{27}$ This database contains measures of output, and bilateral imports and exports for 28 manufacturing industries defined at the three digit International Standard Industrial Classification (ISIC) Revision 2 level for an unbalanced panel of countries. ${ }^{28}$ Output and trade volumes are summed into ten separate industries: (1) food/beverages/tobacco, (2) textiles/apparel/leather, (3) wood/paper, (4) chemicals/plastics/rubber, (5) petroleum/coal, (6) pottery/glass/non-metallic mineral products, (7) iron/steel/metal products, (8) machinery/scientific equipment, and (9) transport equipment, (10) other. Therefore, an industry $K$ corresponds to one of these 10 industries.

U.S. consumption of own production in year $t, X_{n n K t}$, is measured as output less manufacturing exports. Total industry expenditures for a country $i$ in year $t, X_{i K t}$, is measured as output plus net imports in that industry. Bilateral trade with the United States are measured by U.S. reported trade, where $X_{i n K t}$ represents U.S. exports to $i$,

\footnotetext{
${ }^{27}$ The econometric analysis does not extend beyond 2001, as this is the last year U.S. production data are reported in the database.

${ }^{28}$ The production data from this database were collected by UNIDO and OECD through their joint annual collection program of general industrial statistics. However, the production data from UNIDO are subject to differences in national classifications and assumptions are applied in order to convert from the national (country specific) industrial classification into the ISIC classification. These problems, which undermine the international comparability of the data, are generally more pronounced at the more disaggregate level. See Nicita and Olarreaga (2006), and Yamada (2005).
} 
and $X_{n i K t}$ represents U.S. imports from $i$ in industry $K$. Country $i$ 's consumption in an industry, $X_{i K t}$, is measured as output plus net imports in that industry.

Following Eaton and Kortum (2002) annual compensation is adjusted for education to measure wages in efficiency units. Specifically, wages are given by $w_{i t}=\operatorname{comp}_{i t} * e^{-.06 H_{i t}}$ where .06 is an estimate of the return to education, $H_{i t}$ is the average years of schooling of the adult population for country $i$ and $c o m p_{i t}$ is a measure of compensation. ${ }^{29,30}$ In order to preserve as many observations as possible, the preferred measure for worker compensation in a particular year is nominal GDP per worker, translated from local currency units to dollars using average annual exchange rates. GDP data are taken from the World Development Indicators, and the number of workers in a particular year is estimated using data from the Penn World Tables 6.3 obtained by dividing the variable Real GDP purchasing power parity (Chain Index) by the real GDP per worker. Because GDP data may be a noisy measure, as an alternative, I first use hourly compensation taken from the Bureau of Labor Statistics International

\footnotetext{
${ }^{29}$ Eaton and Kortum (2002) use annual compensation per worker in manufacturing for their OECD sample, and adjust this measure for worker quality in the same manner. They reference Bils and Klenow (2000) as sources for this particular measure of the return to education.

${ }^{30}$ Data on educational attainment is taken from Barro and Lee (2001). The measure used is the average years of education for the population age 15 and up. Because the data are only available at five year intervals, the measure for a given year is used for that year as well as the for the immediate two prior and subsequent years.
} 
Labor Comparison (ILC) program also translated in to current U.S. dollars using average annual exchange rates. I show that results are robust to both measures.

The natural $\log$ of the relative state of technology, $\ln \left(T_{i K} / T_{n K}\right)$, is estimated with a country and industry fixed effect and is assumed to be constant across time. ${ }^{31}$ This fixed effect also subsumes the distance term capturing relative transportation costs, also assumed to be constant across time.

U.S. tariff data are taken from the United States Trade Commission's Tariff Database. The database includes the ad valorem, specific, and estimated ad valorem equivalent tariffs based on the Most Favored Nation (MFN) status. In addition, the file indicates commodities that are eligible for tariff preference programs and the applicable tariffs under these programs. The estimated ad valorem equivalent tariff for a particular country applicable under the relevant preference program is used as a measure for U.S. tariffs. If a country/good qualifies for more than one preference program, the minimum tariff of all qualifying programs is used. These data are available for commodity descriptions at the HTS 8-digit level which are then concorded with the ISIC Revision 2 classifications and then aggregated to the industry level noted above.

Ideally, the tariff data for each country would be measured as the average tariff imposed specifically on the United States. For all countries except for Mexico and Canada tariff data are taken from the World Bank’s Trade and Production Database,

\footnotetext{
${ }^{31}$ An alternative strategy would be to transform the equation to a first difference; however, because for many observations data in consecutive years are not available in the panel, there is quite a bit of attrition under this specification resulting in nearly half of the sampled observations being dropped.
} 
1976-2004, which reports several measures of ad valorem tariff rates. The measure used in this paper is the import weighted MFN tariff. Canadian and Mexican tariffs imposed on U.S. goods under CUSFTA and NAFTA are taken from the World Bank's World Integrated Trade Solution Database.

The final specification is given by

$$
\ln \frac{\tilde{X}_{n i K t}}{\tilde{X}_{n n K t}}=\beta_{0}+\beta_{1} \text { relwage }_{n i K t}+\beta_{2} \text { owntariff }_{\text {inKt }}+\beta_{3} \text { ustariff }_{n i K t}+\eta_{i K}+\varepsilon_{i K t}
$$

where $\eta_{i K}$ captures time constant industry-country specific factors, relwage ${ }_{i K t}$ $=\alpha_{K L} * \ln \left(\frac{w_{i t}}{w_{n t}}\right)$, owntariff $i_{i K t}=\sum_{J=1}^{\bar{K}} \alpha_{K J} \ln \left(1+\tau_{i n J t}\right)$, ustariff $i_{i K t}=\ln \left(1+\tau_{n i K t}\right)$, and $\varepsilon_{i K t}$ is the random error term. ${ }^{32}$ In the empirical estimation, production function parameters are measured using the U.S. production data as a benchmark. Labor's share in a particular industry is calculated as the average share of wages in output for the U.S. sample, in a particular industry. These measures are reported in Table $5 .^{33}$ Total intermediate share is

\footnotetext{
${ }^{32}$ This specification bears some resemblance to recent empirical models of Romalis (2004) and Nunn (2007), among others, who have sought to measure the importance of interactions between country and industry specific factors as sources of comparative advantage. Romalis (2004) tests the importance of factor abundance interacted with factor intensity measures and Nunn (2007) extends the model to consider the importance of contract enforcement for contract intensive industries.

${ }^{33}$ In the original specification, the model follows Eaton and Kortum (2002) and ignores capital as an input, allowing for intermediates to play a similar role in the production function. Under this specification, the total intermediate share is one minus labor's share. Additional controls for relative capital costs and financial development are included later when checking the robustness of the results.
} 
given by $\sum_{J=1}^{\bar{K}} \alpha_{K J}=1-\alpha_{K L}$ Individual intermediate industry cost shares, $\alpha_{K J}$, are calculated using the U.S. Input-Output data also provided by World Bank's Trade and Production Database, 1976-2004. The theory requires that $\beta_{1}=\beta_{2}=\beta_{3}=-\theta<0$. In other words the parameter $\theta$ which governs the variation of the distribution of productivity, with less variability implying a bigger $\theta$, determines by how much trade flows respond to changes in relative wages, tariffs, and other cost variables. This restriction is not imposed in the empirical estimates but I do test for whether or not the coefficients are statistically different from each other.

\section{Results}

The final data set for which all data for specification (25) are available consists of an unbalanced panel of 56 trading partner countries when GDP data are used to calculate compensation and 26 countries when hourly compensation measures from the ILC data are used. In all regressions robust standard errors are clustered by country and industry.

Results using hourly compensation to calculate wages are reported in the first four columns of Table 6. In the baseline regression of Column 1, the coefficients of both tariff terms and wages have the expected negative and significant coefficient. However, the magnitudes of the coefficients are not equal as can be seen by the test of equality at the bottom of the column.

In the next few columns, several additional control variables are progressively added. The first modification deals with the concern of whether or not the relative state of 
technology can reasonably be assumed to stay constant across time. ${ }^{34}$ Relative wages and relative levels of productivity are expected to be correlated so incorrect measurement of the relative state of technology could induce a bias especially on the relative wage term. Therefore, it is assumed that relative productivity growth is the same for all industries within a country and the state of technology is proxied by estimating a country and year specific Total Factor Productivity (TFP) term. This measure is calculated as the residual from the regression of the natural log of real GDP on both the natural log of the real capital stock and the available labor force which is also measured in efficiency units. $^{35,36}$ Regression 2 of Table 6 contains the results for the specification that includes the natural log of the relative TFP term. As can be seen, this term has the expected positive sign and is statistically significant. However, the relative wage term decreases in absolute value.

${ }^{34}$ Changes in technology may be especially important as suggested by recent research by Keane and Feinberg (2007) who argue that the advent of improved logistics management practices, including the 'justin-time' (JIT) production system, can explain much of the growth of intra-firm trade. Lileeva and Trefler (2007) argue that tariff cuts can be effective especially in conjunction with new technologies such as justin-time delivery.

${ }^{35}$ Specifically, the available labor force in country $i$ in year $t$ is given by $L_{i t}=p o p_{i t} * e^{.06 H_{i t}}$.

${ }^{36}$ Data and documentation used to construct TFP measures were obtained from a database provided by Adalmir Marquetti at http://homepage.newschool.edu/ foleyd/epwt/. These data are based on the extensions of the Penn World Tables 6.2. Because the Penn World Tables do not currently have capital stock data, the standardized capital stock measure is obtained by applying the Perpetual Inventory Method to the investment series computed from the variable Real Investment Share of GDP. 
In the third column a control for capital market development is added. Therefore in measuring the input shares, while labor's share is still calculated as the share of wages in output, capital's share is calculated as the value added share of output minus labor's share, and the total intermediate share is calculated as 1 minus the value added share of output. Table 8 summarizes the factor cost shares. The control for financial development is the capital share in industry $K$ interacted with the natural $\log$ of the relative private bank credit to GDP ratio. ${ }^{37}$ As can be seen no major changes are attained except that the two tariff terms are no longer statistically different from each other. Finally, added to the regression is a dummy for the Canadian U.S. Free Trade Agreement (CUSFTA) and the North American Free Trade Agreement (NAFTA) to control for other trade liberalizations specific to these free trade agreements that went beyond the scope of tariff decreases but which were likely correlated. The dummy is one for all Canadian observations and 1 for all Mexican observations for 1994 and later. Column 4 shows no significant changes.

Since the data using hourly compensation are limited primarily to developed countries, I now check to see if the GDP per capita make for a reasonable proxy. In Column 5, the same regression is performed using the same sample used in Column 4. As can be seen the coefficients are almost identical. In fact the correlation coefficient between the two relwage measures is .94 and significant at the 1 percent level. Therefore, in all of the following regressions, I use the GDP per worker measure to calculate wages.

\footnotetext{
${ }^{37}$ Relative bank credit to GDP data are taken from the Financial Structure Dataset. See Beck, DemirgüçKunt and Levine (2009).
} 
In the final column of Table 6, the same variables are used but with the additional observations for which GDP per worker data are available. The main effect is to completely remove all significance on the relwage term. In the previous five regressions wage coefficients were consistently lower than the theory suggested. Adding a large amount of developing countries to the sample tends to exacerbate the problem. One concern is that wages are inherently endogenous and that the wage term is picking up part of the productivity effect that is being captured in the error term. The analysis so far has attempted to control for country and industry specific differences in productivity with fixed effects, and with an estimate of TFP that is year and country specific for changes in technology across time. To control for any additional omitted variable bias, an Instrumental Variable (IV) procedure is employed. Following Eaton and Kortum (2002), two primary instruments for relative wages are used: the natural logs of the relative supply of workers, measured in efficiency units, and the relative population density. ${ }^{38}$ In the IV estimation, these primary instruments are used as well as the corresponding interaction with labor's share to instrument for the interaction of the natural log of relative wages with labor's share. The IV results are presented in Regression 2 of Table 9. As can be seen, the result is a significant and larger, in absolute value, coefficient with the expected negative sign. In addition, the Hausman test of exogeneity rejects the null of exogeneity at the 1 percent level. The exclusion restrictions for the instruments are also met at the 1 percent level. The tariff terms remain statistically significant and the test of

\footnotetext{
${ }^{38}$ Labor supply for country $i$ measured in efficiency units is measured as $L_{i t}=p o p_{i t} * e^{.06 H_{i t}}$. Population density is measured as the population divided by land area.
} 
equality of the coefficients of the two tariff terms and the relwage term cannot be rejected at the 1 percent level. Therefore, these results do adhere to the restrictions of the Eaton and Kortum theory.

To check the robustness of the results, outcomes from three alternative regressions are reported in Table 9. To insure that the NAFTA countries do not make an important difference in Column 1 of Table 9, Canada and Mexico are dropped as well as the CUSFTA/NAFTA dummy. In the second regression, all observations pertaining to the textile industry are dropped. This is because the textile industry has historically been subjected to substantial non-tariff barriers, and consequently tariffs may not accurately measure trade restrictions in this industry. In the third specification, the relwage term is replaced by the relative labor supply interacted with labor intensity. ${ }^{39}$ No significantly different results are attained. In the first two regressions the U.S. tariff is marginally lower and the owntariff term is marginally higher. In the third regression, the relative labor supply interaction is positive and significant as expected.

Finally, in Table 10, the regression is performed with only high income countries in the sample. This alternative is to allow for the possibility that high income countries may have a different degree of technological heterogeneity than low income countries suggesting that the regression (25) would only be appropriate for high income countries. The results are compared to the full sample without the CUSFTA/NAFTA dummy since this would not be identified in the full sample. The only changes are that the financial

\footnotetext{
${ }^{39}$ This specification is directly related to that of Romalis (2004), Levechenko (2007), and Nunn (2007) who interact factor intensities with factor abundance.
} 
development control variable is insignificant for the selected sample and the owntariff terms is marginally less significant.

In all specifications the coefficient on U.S. tariffs is marginally larger than that of exporting country tariffs; however, as was noted in the descriptive statistics, U.S. liberalizations have been relatively moderate especially in comparison to the substantial liberalizations by the least developed countries. In order to study the suggested effects of actual trade liberalization for the sample, the implied change in trade suggested by the model is calculated over the widest time frame for which exporting country tariff data are available. The specification used is that of Regression 2 of Table 8. These results are given in Table 11. As can be seen, for especially some countries their own liberalizations have been relatively more important. For example, the impact of China's own liberalizations, with an average increase to the left hand side variable of .490, was over 6.7 times the effect of U.S. tariff liberalization with only an implied increase to the left hand side variable of .073. Taking the average effect of tariff liberalizations across countries, Table 12 shows that on average exporting country liberalizations have been an important source of comparative advantage and quantitatively more important than U.S. liberalizations. For the entire sample, countries’ own liberalization was 2.3 times larger than U.S. liberalization. However, for the least developed countries, their own liberalizations have been on average 4.2 times more important than U.S. liberalizations and for lower middle income countries their own liberalizations have been 2.6 times as large. For high income countries, U.S. tariff decreases have had a marginally larger effect, on average. 


\section{Conclusion}

Throughout the 1960's and 1970’s, many developing countries erected highly protected trade regimes in the hopes of expanding the industrial sectors of their economies. The standard rationale behind protectionist measures falls under the infant industry argument which theorizes that protectionism will allow an infant industry to grow and develop to the point at which it can compete on international markets without protectionist measures. Other proponents of trade protection argue that domestic firms should be more able to invest in new infrastructure and modern production techniques if guaranteed protection from foreign competition. While developing countries have for some time adhered to the more conventional wisdom that greater openness to foreign competition induces both productivity and welfare gains, developing countries have only recently begun to abandon development through protection policies. For some countries recent trade liberalizations have been substantial and have also coincided with large export growth rates which have far outpaced those of high income countries.

This paper was in part motivated by the observation that U.S. imports from less developed countries are becoming increasingly important in U.S. trade, and consequently imply that when analyzing trade growth limiting one's sample to a balanced panel of the most developed countries at the time, may result in neglecting important sources and causes of trade growth. This paper investigates whether or not the more pronounced export growth of less developed countries is related to recent trade liberalizations by promoting the development of vertical production networks. 
To investigate this hypothesis, I build and estimate an empirical model that is guided by extensions of the Eaton and Kortum (2002) model. The objective is to relate an appropriate measure of bilateral trade, which correctly controls for trade policies with other countries, to both importing and exporting country tariff policy. The results suggest that both intermediate tariffs imposed by countries exporting to the United States as well as U.S. tariffs matter for trade. Higher U.S. tariffs are associated with less trade, and countries with low intermediate tariffs tend to have higher levels of trade as measured in this paper. Empirical studies estimating trade elasticities have tended to focus on importer barriers and not to directly measure the importance of exporter country policies. My results indicate that especially for less developed countries who have historically had much more protected trade regimes, their own liberalizations have been relatively more important than U.S. tariffs, which in turn have been quite moderate. 
Table 1

US Trading Partners Represented in the the Descriptive Statisitcs

\begin{tabular}{lll}
\hline Tanzania & Ecuador & Ireland \\
Uganda & Turkey & Israel \\
Malawi & Panama & Greece \\
Benin & Tunisia & New Zealand \\
Ghana & Algeria & Spain \\
Mozambique & Jordan & Oman \\
Nigeria & Botswana & Singapore \\
Nepal & Colombia & Macao \\
Bangladesh & Costa Rica & United Kingdom \\
China & Malaysia & Italy \\
Senegal & South Africa & France \\
India & Brazil & Finland \\
Kenya & Mexico & Sweden \\
Pakistan & Poland & Denmark \\
Bolivia & Chile & Germany \\
Sri Lanka & Uruguay & Belgium \\
Cameroon & Trinidad and Tobago & Australia \\
Indonesia & Venezuela & Netherlands \\
Ivory Coast & Mauritius & Hong Kong \\
Honduras & Argentina & Austria \\
Philippines & Gabon & Japan \\
Egypt & South Korea & Iceland \\
El Salvador & Hungary & Canada \\
Peru & Taiwan & Norway \\
Morocco & Malta & Kuwait \\
Guatemala & Portugal & Switzerland \\
Thailand & Cyprus & Qatar \\
& & \\
\hline Ordered by 1989 per capita GDP (Constant 2005 dollars) \\
Sara
\end{tabular}


Table 2

Growth of US Imports/Output and US Tafiff Liberalization 1989-2001

\begin{tabular}{|c|c|c|c|}
\hline Year & US imports/US output & Average US tariff & \\
\hline 1989 & 0.149 & 0.052 & \\
\hline 1990 & 0.149 & 0.049 & \\
\hline 1991 & 0.154 & 0.048 & \\
\hline 1992 & 0.159 & 0.046 & \\
\hline 1993 & 0.167 & 0.046 & \\
\hline 1994 & 0.180 & 0.043 & \\
\hline 1995 & 0.188 & 0.043 & \\
\hline 1996 & 0.182 & 0.041 & \\
\hline 1997 & 0.195 & 0.039 & \\
\hline 1998 & 0.206 & 0.038 & \\
\hline 1999 & 0.222 & 0.035 & \\
\hline 2000 & 0.245 & 0.035 & \\
\hline 2001 & 0.265 & 0.034 & \\
\hline \multicolumn{4}{|l|}{$\Delta$} \\
\hline $1989-2001$ & $\Delta \ln ($ US imports/US output) & $\Delta \ln (1+$ tariff $)$ & Trade to Tariff Elasticity \\
\hline & 0.58 & -0.02 & -33.57 \\
\hline
\end{tabular}

Tariff measure is import weighted average US ad valorem equivalent tariff across manufacturing industries. 
Table 3

Implied Trade Elasticities of US Manufacturing Imports/US Manufacturing Output to US Gross Tariffs

\begin{tabular}{|c|c|c|c|}
\hline Country/Country Group & $\begin{array}{c}1989-2001 \\
\Delta \ln (\text { US imports/US output) }\end{array}$ & $\begin{array}{c}1989-2001 \\
\Delta \ln (1+\text { tariff })\end{array}$ & Elasticity \\
\hline$\overline{\text { World }}$ & 0.578 & -0.017 & -33.57 \\
\hline Canada & 0.487 & -0.041 & -11.84 \\
\hline Mexico & 1.444 & -0.027 & -54.02 \\
\hline China & 2.117 & -0.008 & -266.64 \\
\hline Least Developed $^{1}$ & 1.015 & -0.008 & -133.68 \\
\hline Lower Middle Income ${ }^{2}$ & 0.848 & -0.006 & -138.90 \\
\hline Upper Middle Income ${ }^{3}$ & 0.453 & -0.007 & -67.39 \\
\hline High Income $^{4}$ & 0.230 & -0.007 & -32.80 \\
\hline
\end{tabular}

Tariff measure is import weighted average US ad valorem equivalent tariff across manufacturing industries.

1 All countries with 1989 per capita GDP (Constant 2005 dollars) <\$3000 (excluding China)

2 All countries with 1989 per capita GDP (Constant 2005 dollars) between $\$ 3000$ and \$10,000 (excluding Mexico)

3 All countries with 1989 per capita GDP (Constant 2005 dollars) between $\$ 10000$ and \$18,000

4 All countries with 1989 per capita GDP (Constant 2005 dollars) greater than \$18,000 (excluding Canada) 
Table 4

Trends in Tariffs by Country/Country Group

\begin{tabular}{|c|c|c|c|c|c|c|c|c|c|c|c|c|c|c|}
\hline Country/Country Group & 1989 & 1990 & 1991 & 1992 & 1993 & 1994 & 1995 & 1996 & 1997 & 1998 & 1999 & 2000 & 2001 & $\begin{array}{c}\Delta \ln (1+\text { tariff }) \\
\text { percent }\end{array}$ \\
\hline \multirow[t]{2}{*}{ World } & 0.18 & 0.18 & 0.13 & 0.16 & 0.15 & 0.17 & 0.14 & 0.11 & 0.13 & 0.13 & 0.11 & 0.11 & 0.11 & $-6.04 \%$ \\
\hline & 0.30 & 0.24 & 0.14 & 0.20 & 0.18 & 0.23 & 0.17 & 0.14 & 0.18 & 0.15 & 0.13 & 0.13 & 0.13 & $1989-2001$ \\
\hline \multirow[t]{2}{*}{ Canada } & 0.07 & . & . & . & 0.03 & . & . & . & 0.01 & 0.00 & 0.00 & 0.00 & 0.00 & $-6.71 \%$ \\
\hline & 0.06 & . & . & . & 0.03 & . & . & . & 0.01 & 0.00 & 0.00 & 0.00 & 0.00 & $1989-2001$ \\
\hline \multirow[t]{2}{*}{ Mexico } & . & . & 0.13 & . & . & . & 0.06 & . & . & . & 0.04 & . & . & $-8.17 \%$ \\
\hline & . & . & 0.03 & . & . & . & 0.06 & . & . & . & 0.05 & . & . & 1991-1999 \\
\hline \multirow[t]{2}{*}{ China } & . & . & . & 0.47 & 0.45 & 0.41 & . & 0.27 & 0.20 & 0.20 & 0.19 & 0.18 & 0.17 & $-22.46 \%$ \\
\hline & - & . & - & 0.31 & 0.31 & 0.30 & . & 0.17 & 0.14 & 0.14 & 0.14 & 0.14 & 0.12 & $1992-2001$ \\
\hline \multirow[t]{2}{*}{ Least Developed $^{1}$} & 0.76 & 0.60 & . & 0.49 & 0.15 & 0.37 & 0.30 & 0.21 & 0.23 & 0.26 & 0.23 & 0.18 & 0.19 & $-39.32 \%$ \\
\hline & 0.62 & 0.49 & . & 0.44 & 0.09 & 0.35 & 0.22 & 0.15 & 0.20 & 0.19 & 0.18 & 0.13 & 0.14 & $1989-2001$ \\
\hline \multirow[t]{2}{*}{ Lower Middle Income ${ }^{2}$} & 0.32 & 0.23 & 0.19 & 0.17 & 0.23 & 0.17 & 0.17 & 0.15 & 0.17 & 0.17 & 0.13 & 0.14 & 0.14 & $-14.62 \%$ \\
\hline & 0.19 & 0.17 & 0.16 & 0.10 & 0.20 & 0.15 & 0.12 & 0.16 & 0.24 & 0.17 & 0.13 & 0.15 & 0.14 & $1989-2001$ \\
\hline \multirow[t]{2}{*}{ Upper Middle Income ${ }^{3}$} & 0.11 & 0.11 & 0.11 & 0.10 & 0.10 & 0.09 & 0.10 & 0.09 & 0.08 & 0.06 & 0.07 & 0.05 & 0.05 & $-5.07 \%$ \\
\hline & 0.12 & 0.12 & 0.14 & 0.11 & 0.13 & 0.14 & 0.19 & 0.11 & 0.09 & 0.06 & 0.08 & 0.05 & 0.06 & 1989-2001 \\
\hline \multirow[t]{2}{*}{ High Income $^{4}$} & 0.07 & 0.09 & 0.09 & 0.09 & 0.09 & 0.09 & 0.09 & 0.06 & 0.06 & 0.05 & 0.05 & 0.04 & 0.04 & $-3.01 \%$ \\
\hline & 0.11 & 0.12 & 0.13 & 0.13 & 0.12 & 0.14 & 0.19 & 0.09 & 0.07 & 0.06 & 0.08 & 0.06 & 0.06 & 1989-2001 \\
\hline
\end{tabular}

Notes: For all countries except Mexico and Canada the tariff measure is the average import weighted MFN tariff for manfufacturing industries with standard deviations in italics. For Mexico and Canada, the tariff reported is the average tariff imposed on U.S. manufacturing products under NAFTA and CUSFTA.

1 All countries with 1989 per capita GDP (Constant 2005 dollars) $<\$ 3000$ (excluding China)

2 All countries with 1989 per capita GDP (Constant 2005 dollars) between \$3000 and \$10,000 (excluding Mexico)

3 All countries with 1989 per capita GDP (Constant 2005 dollars) between \$10000 and \$18,000

4 All countries with 1989 per capita GDP (Constant 2005 dollars) greater than \$18,000 (excluding Canada) 
Table 5

Average labor share of output by manufacturing sector, US production

Industry

Labor Share $^{1}$

Food, Beverages and Tobacco

Textile, Wearing Apparel and Leather Industries

Wood Products, Paper Products, Printing and Publishing

Products of Petroleum and Coal

0.19

Chemical, Plastic, and Rubber Products

0.19

0.05

Pottery, Glass, and other Non-metallic Mineral Products

0.15

0.23

Basic Iron, Steel, and Metal Products

0.15

Fabricated Metal Products and Professional and Scientific Equipment

0.21

Transport equipment

0.21

Mean

0.16

1 Labor share is the average share of wages in output. 


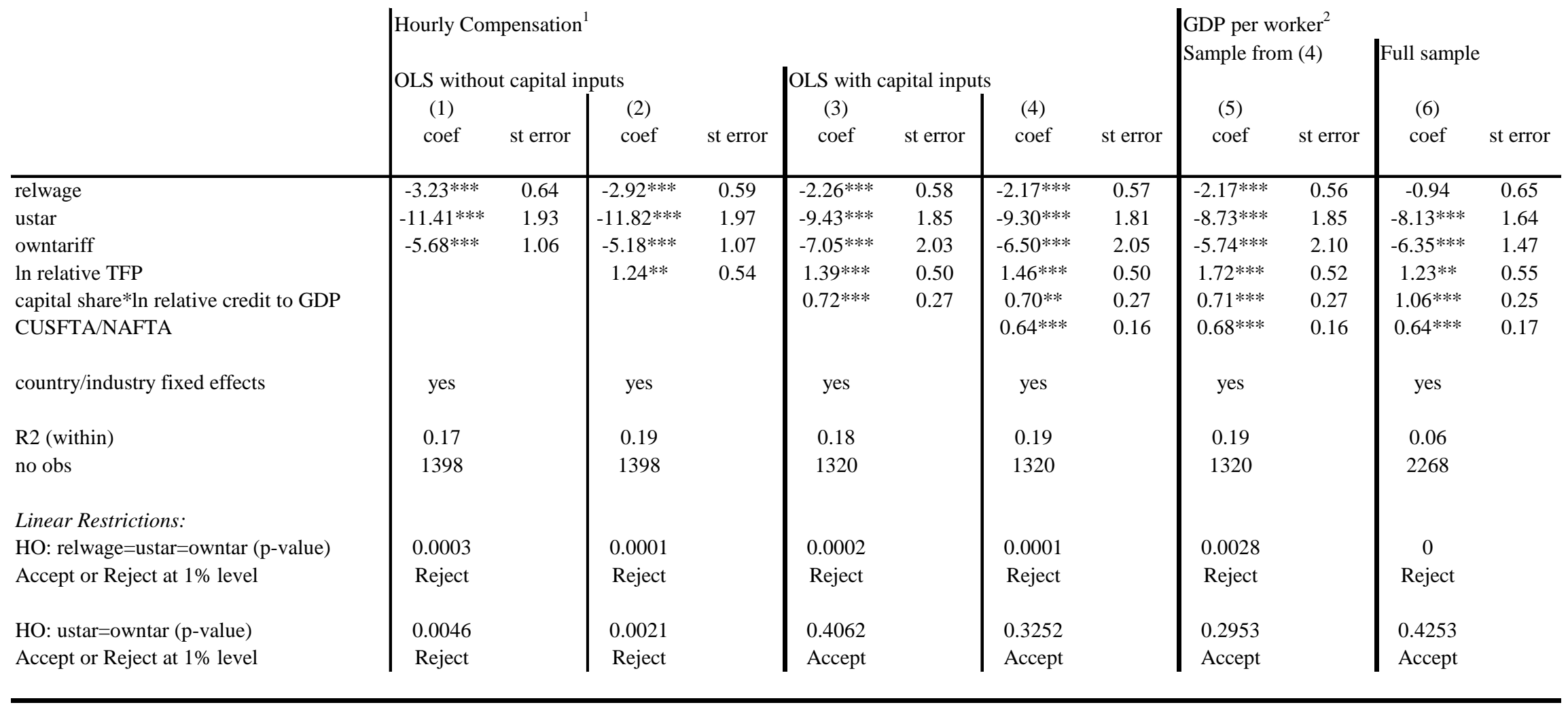

1 relwage term calculated using hourly compensation.

2 relwage term calculated using GDP per worker.

Robust standard errors are clustered by country and industry.

***Significant at the $1 \%$ level, **Significant at the 5\% level, *Significant at the $10 \%$ level. 
Table 7

Average input shares of output by manufacturing sector, US production

\begin{tabular}{|c|c|c|c|}
\hline Industry & Labor Share $^{1}$ & Capital Share $^{2}$ & Intermediate Share $^{3}$ \\
\hline Food, Beverages and Tobacco & 0.07 & 0.47 & 0.45 \\
\hline Textile, Wearing Apparel and Leather Industries & 0.19 & 0.29 & 0.53 \\
\hline Wood Products, Paper Products, Printing and Publishing & 0.19 & 0.30 & 0.51 \\
\hline Products of Petroleum and Coal & 0.05 & 0.19 & 0.76 \\
\hline Chemical, Plastic, and Rubber Products & 0.15 & 0.38 & 0.47 \\
\hline Pottery, Glass, and other Non-metallic Mineral Products & 0.23 & 0.38 & 0.39 \\
\hline Basic Iron, Steel, and Metal Products & 0.15 & 0.24 & 0.61 \\
\hline Fabricated Metal Products and Professional and Scientific Equipment & 0.21 & 0.35 & 0.44 \\
\hline Transport equipment & 0.15 & 0.24 & 0.61 \\
\hline Other & 0.21 & 0.34 & 0.45 \\
\hline Mean & 0.16 & 0.32 & 0.52 \\
\hline
\end{tabular}

1 Labor share is caluclated as labor payments/output.

A 2 Captial Share is calculated as value added/output - labor share.

क 3 Intermediate share is 1-capital share-labor share. 


\begin{tabular}{|c|c|c|c|c|}
\hline$\underline{\text { OLS and second stage IV estimates }}$ & $\begin{array}{c}\text { OLS } \\
\text { (1) } \\
\text { coef }\end{array}$ & st error & $\begin{array}{c}\text { IV } \\
(2) \\
\text { coef } \\
\end{array}$ & st error \\
\hline relwage & -0.94 & 0.65 & $-4.98 * *$ & 2.48 \\
\hline ustar & $-8.13 * * *$ & 1.64 & $-6.73 * * *$ & 1.79 \\
\hline owntariff & $-6.35 * * *$ & 1.47 & $-5.15 * * *$ & 1.68 \\
\hline In relative TFP & $1.23^{* *}$ & 0.55 & $1.45^{* *}$ & 0.64 \\
\hline capital share*ln relative credit to GDP & $1.06^{* * *}$ & 0.25 & $1.22 * * *$ & 0.26 \\
\hline CUSFTA/NAFTA & $0.64 * * *$ & 0.17 & $0.55 *$ & 0.19 \\
\hline labor share*ln relative labor supply & & & & \\
\hline country/industry dummies & yes & & yes & \\
\hline \multicolumn{5}{|l|}{ First stage IV estimates: } \\
\hline In relative labor supply & & & -0.03 & 0.08 \\
\hline In relative labor supply*labor share & & & $-1.60 * *$ & 0.61 \\
\hline In relative population density & & & 0.01 & 0.09 \\
\hline In relative population density *labor share & & & $2.66 * * *$ & 0.70 \\
\hline no obs & 2268 & & 2204 & \\
\hline Hausman Test (p-value) & & & 0.0003 & \\
\hline Over-id test (p-value) & & & 0.0244 & \\
\hline \multicolumn{5}{|l|}{ Linear Restrictions: } \\
\hline HO: relwage $=$ ustar $=$ owntar ( $p$-value $)$ & 0 & & 0.7469 & \\
\hline Accept or Reject at $1 \%$ level & Reject & & Accept & \\
\hline HO: ustar=owntar (p-value) & 0.4253 & & 0.4800 & \\
\hline Accept or Reject at $1 \%$ level & Accept & & Accept & \\
\hline
\end{tabular}

Robust standard errors are clustered by country and industry.

***Significant at the $1 \%$ level, **Significant at the $5 \%$ level, *Significant at the $10 \%$ level. 


\begin{tabular}{|c|c|c|c|c|c|c|c|c|}
\hline First and second stage IV estimates & \multicolumn{2}{|c|}{\begin{tabular}{|} 
IV \\
Full Sample \\
(1)
\end{tabular}} & \multicolumn{2}{|c|}{$\begin{array}{c}\text { IV } \\
\text { No NAFTA } \\
(2)\end{array}$} & \multicolumn{2}{|c|}{\begin{tabular}{|l} 
IV \\
No Textiles \\
$(3)$
\end{tabular}} & \multicolumn{2}{|c|}{$\begin{array}{l}\text { OLS } \\
\text { Relative labor } \\
\text { (4) }\end{array}$} \\
\hline relwage & $-4.98 * *$ & 2.48 & $-5.45^{* *}$ & 2.42 & $-5.50 *$ & 2.89 & & \\
\hline ustar & $-6.73 * * *$ & 1.79 & $-5.43 * * *$ & 1.80 & $-5.40 * * *$ & 1.81 & $-8.97 * * *$ & 1.65 \\
\hline owntariff & $-5.15^{* * *}$ & 1.68 & $-4.67 * * *$ & 1.67 & $-5.02 * * *$ & 1.80 & $-6.39 * * *$ & 1.42 \\
\hline ln relative TFP & $1.45^{* *}$ & 0.64 & $1.42^{* *}$ & 0.66 & $1.39 *$ & 0.74 & $1.25 * *$ & 0.53 \\
\hline capital share*ln relative credit to GDP & $1.22 * * *$ & 0.26 & $1.29 * * *$ & 0.28 & $1.14^{* * *}$ & 0.29 & $1.00 * * *$ & 0.24 \\
\hline CUSFTA/NAFTA & $0.55^{*}$ & 0.19 & & & $0.38 * * *$ & 0.14 & $0.62 * * *$ & 0.16 \\
\hline labor share*ln relative labor supply & & & & & & & $7.78^{* *}$ & 3.94 \\
\hline country/industry dummies & yes & & yes & & yes & & yes & \\
\hline \multicolumn{9}{|l|}{ First stage IV estimates: } \\
\hline ln relative labor supply & -0.03 & 0.08 & -0.02 & 0.09 & -0.02 & 0.08 & & \\
\hline In relative labor supply*labor share & $-1.60 * *$ & 0.61 & $-1.71 * * *$ & 0.62 & $-1.54^{\star \star}$ & 0.64 & & \\
\hline In relative population density & 0.01 & 0.09 & 0.02 & 0.09 & 0.01 & 0.10 & & \\
\hline In relative population density*labor share & $2.66^{* * *}$ & 0.70 & $2.91^{* * *}$ & 0.69 & $2.61^{\star \star \star}$ & 0.75 & & \\
\hline no obs & 2204 & & 2111 & & 1952 & & 2268 & \\
\hline Hausman Test (p-value) & 0.0003 & & 0.0002 & & 0.0003 & & & \\
\hline Over-id test (p-value) & 0.0244 & & 0.0389 & & 0.0633 & & & \\
\hline \multicolumn{9}{|l|}{ Linear Restrictions: } \\
\hline HO: relwage $=$ ustar $=$ owntar ( $p$-value $)$ & 0.7469 & & 0.9419 & & 0.9853 & & & \\
\hline Accept or Reject at $1 \%$ level & Accept & & Accept & & Accept & & & \\
\hline HO: ustar=owntar (p-value) & 0.4800 & & 0.7389 & & 0.8719 & & 0.07 & \\
\hline Accept or Reject at $1 \%$ level & Accept & & Accept & & Accept & & Accept & \\
\hline
\end{tabular}

Robust standard errors are clustered by country and industry.

***Significant at the $1 \%$ level, **Significant at the 5\% level, *Significant at the $10 \%$ level. 


\begin{tabular}{|c|c|c|c|c|}
\hline \multirow[b]{2}{*}{ First and second stage IV estimates } & \multicolumn{2}{|c|}{$\begin{array}{c}\text { IV } \\
\text { Full Sample } \\
\text { (1) }\end{array}$} & \multicolumn{2}{|c|}{$\begin{array}{c}\text { IV } \\
\text { High Income }^{1} \\
\text { (2) }\end{array}$} \\
\hline & coef & st error & coef & st error \\
\hline$\overline{\text { relwage }}$ & $-4.98 * *$ & 2.48 & $-4.33^{* *}$ & 1.93 \\
\hline ustar & $-6.73 * * *$ & 1.79 & $-6.62 * * *$ & 2.52 \\
\hline owntariff & $-5.15^{* * *}$ & 1.68 & $-5.73^{*}$ & 3.46 \\
\hline ln relative TFP & $1.45^{* *}$ & 0.64 & $1.85^{* *}$ & 0.80 \\
\hline capital share*ln relative credit to GDP & $1.22 * * *$ & 0.26 & 0.60 & 0.38 \\
\hline CUSFTA/NAFTA & $0.55^{*}$ & 0.19 & & \\
\hline country/industry dummies & yes & & yes & \\
\hline \multicolumn{5}{|l|}{ First stage IV estimates: } \\
\hline ln relative labor supply & -0.03 & 0.08 & $-0.16^{*}$ & 0.08 \\
\hline In relative labor supply*labor share & $-1.60 * *$ & 0.61 & $-1.16^{*}$ & 0.65 \\
\hline In relative population density & 0.01 & 0.09 & 0.00 & 0.09 \\
\hline In relative population density*labor share & $2.66^{* * *}$ & 0.70 & 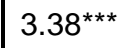 & 0.57 \\
\hline no obs & 2204 & & 1023 & \\
\hline Hausman Test (p-value) & 0.0003 & & 0.0889 & \\
\hline Over-id test (p-value) & 0.0244 & & 0.4989 & \\
\hline \multicolumn{5}{|l|}{ Linear Restrictions: } \\
\hline HO: relwage $=$ ustar $=$ owntar ( $\mathrm{p}$-value $)$ & 0.7469 & & 0.827 & \\
\hline Accept or Reject at $1 \%$ level & Accept & & Accept & \\
\hline HO: ustar=owntar (p-value) & 0.4800 & & 0.8008 & \\
\hline Accept or Reject at $1 \%$ level & Accept & & Accept & \\
\hline
\end{tabular}

1 Only countries with 1989 per capita GDP (Constant 2005 dollars) greater than \$18,000 in sample.

Robust standard errors are clustered by country and industry.

***Significant at the $1 \%$ level, **Significant at the $5 \%$ level, *Significant at the $10 \%$ level 
Table 11 Average predicted effect of tariff liberalization, by country

\begin{tabular}{|c|c|c|c|c|c|c|c|c|c|c|c|}
\hline Country Name & Time Frame & $\Delta \mathrm{hs}$ & $-6.73 * \Delta$ Inustar & $-5.15 * \Delta$ owntariff & Income ${ }^{1}$ & Country Name & Time Frame & $\Delta \mathrm{lhs}$ & $-6.73 * \Delta$ lnustar & $-5.15 * \Delta$ owntariff & Income $^{1}$ \\
\hline Bangladesh & 1989-2000 & & 0.067 & 1.281 & 1 & South Africa & 1990-2001 & 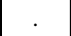 & 0.197 & 0.071 & 2 \\
\hline Bolivia & $1993-2001$ & & -0.030 & 0.015 & 1 & Sri Lanka & 1990-2001 & . & 0.069 & 0.315 & 2 \\
\hline China & 1992-2001 & & 0.073 & 0.490 & 1 & Thailand & 1989-2001 & . & 0.070 & 0.411 & 2 \\
\hline Ghana & 1993-2000 & & 0.073 & -0.143 & 1 & Trinidad and Tobago & 1991-2001 & . & -0.019 & 0.204 & 2 \\
\hline India & $1990-2001$ & 1.485 & 0.069 & 0.710 & 1 & Tunisia & 1990-1998 & . & 0.058 & -0.028 & 2 \\
\hline Kenya & 1994-2001 & 1.328 & 0.075 & 0.262 & 1 & Turkey & |1993-1999 & 0.85 & 0.073 & 0.071 & 2 \\
\hline Malawi & 1994-2001 & & 0.075 & 0.324 & 1 & Uruguay & $1992-2001$ & 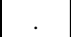 & 0.055 & -0.159 & 2 \\
\hline Nepal & 1993-2000 & & 0.073 & -0.037 & 1 & Venezuela & 1992-2000 & r. & 0.052 & 0.084 & 2 \\
\hline Nigeria & 1989-2001 & . & 0.200 & 0.087 & 1 & Greece & 1989-2001 & . & 0.075 & 0.071 & 3 \\
\hline Pakistan & $1995-2001$ & . & 0.082 & 0.606 & 1 & Hungary & 1991-1997 & 0.74 & 0.049 & 0.075 & 3 \\
\hline Tanzania & $1993-2000$ & . & 0.073 & 0.023 & 1 & Ireland & 1989-2001 & . & 0.075 & 0.071 & 3 \\
\hline Uganda & 1994-2001 & . & 0.075 & 0.189 & 1 & South Korea & 1989-1999 & 0.11 & 0.069 & 0.142 & 3 \\
\hline Algeria & 1993-2001 & . & 0.074 & 0.051 & 2 & Malta & 1997-2000 & 0.39 & 0.007 & -0.001 & 3 \\
\hline Argentina & 1992-2001 & & 0.055 & -0.020 & 2 & New Zealand & 1992-2000 & . & 0.068 & 0.164 & 3 \\
\hline Brazil & 1989-2001 & . & 0.070 & 0.471 & 2 & Portugal & 1989-2001 & 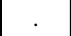 & 0.075 & 0.071 & 3 \\
\hline Cameroon & 1994-2001 & . & 0.075 & -0.005 & 2 & Taiwan & 1989-2001 & . & 0.075 & 0.143 & 3 \\
\hline Chile & 1992-2001 & . & 0.055 & 0.072 & 2 & Australia & 1991-2001 & -0.13 & 0.075 & 0.167 & 4 \\
\hline Colombia & 1991-2001 & 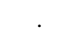 & 0.088 & -0.123 & 2 & Austria & 1990-2001 & . & 0.072 & 0.154 & 4 \\
\hline Costa Rica & 1995-2001 & 0.260 & -0.006 & 0.108 & 2 & Belgium & 1989-2001 & . & 0.075 & 0.071 & 4 \\
\hline Ecuador & 1993-1999 & 0.659 & -0.033 & -0.088 & 2 & Canada & 1989-2001 & 1.30 & 0.247 & 0.209 & 4 \\
\hline Egypt & 1995-1998 & 0.415 & 0.071 & 0.106 & 2 & Denmark & 1989-2001 & . & 0.075 & 0.071 & 4 \\
\hline El Salvador & $1995-2001$ & & -0.006 & 0.066 & 2 & Germany & 1989-2001 & . & 0.075 & 0.071 & 4 \\
\hline Gabon & $1995-2001$ & & 0.186 & 0.009 & 2 & Finland & 1992-2001 & . & 0.073 & 0.056 & 4 \\
\hline Guatemala & 1995-2001 & . & -0.006 & 0.062 & 2 & France & 1989-2001 & . & 0.075 & 0.071 & 4 \\
\hline Honduras & 1995-2001 & . & -0.006 & 0.028 & 2 & Iceland & 1993-2001 & . & 0.074 & 0.038 & 4 \\
\hline Indonesia & 1989-2001 & r & 0.070 & 0.259 & 2 & Italy & $1989-2001$ & . & 0.075 & 0.071 & 4 \\
\hline Ivory Coast & 1993-2001 & . & 0.076 & 0.301 & 2 & Japan & 1989-2001 & 0.14 & 0.075 & 0.041 & 4 \\
\hline Jordan & 2000-2001 & 0.459 & 0.002 & 0.173 & 2 & Netherlands & 1989-2001 & . & 0.075 & 0.071 & 4 \\
\hline Malaysia & 1991-2001 & 1.160 & -0.067 & 0.100 & 2 & Norway & 1993-2001 & 0.35 & 0.074 & 0.087 & 4 \\
\hline Mauritius & 1995-1998 & 0.445 & 0.071 & 0.139 & 2 & Oman & 1992-1997 & . & 0.045 & 0.034 & 4 \\
\hline Mexico & 1991-2001 & & 0.120 & 0.226 & 2 & Singapore & 1989-2001 & 0.16 & 0.075 & 0.041 & 4 \\
\hline Morocco & 1993-2001 & 0.324 & 0.076 & 0.529 & 2 & Spain & 1989-2001 & . & 0.075 & 0.071 & 4 \\
\hline Panama & $1997-2001$ & r. & 0.007 & 0.146 & 2 & Sweden & 1989-2001 & . & 0.075 & 0.004 & 4 \\
\hline Peru & $1993-2000$ & . & -0.032 & 0.114 & 2 & Switzerland & 2000-2001 & . & 0.005 & 0.000 & 4 \\
\hline Philippines & 1989-2001 & . & 0.070 & 0.464 & 2 & United Kingdom & 1989-2001 & . & 0.075 & 0.071 & 4 \\
\hline Poland & 1991-2001 & & 0.058 & 0.004 & 2 & & & & & & \\
\hline
\end{tabular}

Sampled over observations with data for own country tariffs. Observations are average across industries.Countries are divided into income groups by 1989 per capita GDP

(constant 2005 dollars): 1 less than $\$ 3,000,2$ betw een $\$ 3,000$ and $\$ 10,000$, 3 betw een $\$ 10,000$ and $\$ 18,000$, and 4 higher than $\$ 10,000$. 
Table 12

Average predicted effect of tariff liberalization, by income group

\begin{tabular}{l|c|c|c} 
Income Group $^{1}$ & mean $\Delta \mathrm{lhs}$ & $-6.73 *($ mean $\Delta$ lnustar $)$ & $-5.15^{*}($ mean $\Delta$ owntariff $)$ \\
\hline Least Developed $^{1}$ & 1.44 & 0.08 & 0.32 \\
120 observations & 1.06 & 0.10 & 0.42 \\
Lower Middle Income $^{2}$ & 0.66 & 0.05 & 0.13 \\
320 observations & 0.99 & 0.10 & 0.19 \\
Upper Middle Income $^{3}$ & 0.33 & 0.06 & 0.09 \\
80 observations & 0.89 & 0.10 & 0.07 \\
High Income $^{4}$ & 0.51 & 0.08 & 0.07 \\
190 observations & 1.03 & 0.11 & 0.07 \\
Total & 0.64 & 0.06 & 0.14 \\
& 1.02 & 0.11 & 0.24
\end{tabular}

Obervations from Table 11 have been averaged by income group. Standard deviations in italics.

ч S Sampled over observations with data for own country tariffs. Observations are average across industries.

Countries are divided into income groups by 1989 per capita GDP (constant 2005 dollars): 1 less than \$3,000,

2 between $\$ 3,000$ and $\$ 10,000$, 3 between $\$ 10,000$ and $\$ 18,000$, and 4 higher than $\$ 10,000$. 


\section{References}

Anderson, M. A., Balistreri, E. J., Fox, A. K., and Hillberry, R. H., 2005. Taste Parameters as Model Residuals: Assessing the 'Fit' of an Armington Trade Model. Review of International Economics 13, 973--984.

Anderson, James E., and Eric van Wincoop. 2003. “Gravity with Gravitas: A Solution to the Border Puzzle.” American Economic Review, 90(1): 170-192.

Baier, Scott L., and Jeffrey H. Bergstrand. 2001. "The Growth of World Trade: Tariffs, Transport Costs, and Income Similarity.” Journal of International Economics 53(1): 1-27.

Baldwin, Richard E., and Anthony J. Venables. 1995. “Regional Economic Integration.” In Handbook of International Economics Volume 3, ed. G. Grossman and K. Rogoff, 1597-1644. Amsterdam: North Holland.

Barro, Robert J., and Jong-Wha Lee. 2001. "International Data on Educational Attainment: Updates and Implications.” Oxford Economic Papers, 53(3): 541563.

Beck , Thorsten, Asli Demirgüç-Kunt, and Ross Levine. 2009. “Financial Institutions and Markets across Countries and over Time: Data and Analysis.” World Bank Policy Research Working Paper 4943.

Bernard, Andrew B., J. Bradford Jensen. 2004a. "Entry, Expansion and Intensity in the U.S. Export Boom, 1987-1992.” Review of International Economics, 12(4): 662675. 
Bernard, Andrew B., J. Bradford Jensen. 2004b. "Why some Firms Export.” Review of Economics and Statistics, 86(2): 561-569.

Bils, Mark, and Peter J. Klenow. 2000. "Does Schooling Cause Growth?” American Economic Review, 90(5): 1160-1183.

Brock, William A., and Stephen P. Magee. 1978. “The Economics of Special Interest Politics: The Case of the Tariff.” American Economic Review, 68(2): 246-50.

Broda, Christian, and David E. Weinstein. 2006. "Globalization and the Gains from Variety.” Quarterly Journal of Economics, 121(2): 541-585.

Brown, Drussilla K., Alan V. Deardorff, and Robert Stern. 1995. "Estimates of a North America Free Trade Agreement.” In Modeling North American Economic Integration, ed. P. J. Kehoe and T. J. Kehoe, Kluwer Academic Publishers.

Chaney, Thomas. 2008. "Distorted Gravity: the Intensive and Extensive Margins of International Trade.” American Economic Review, 98(4): 1707-21.

Chor, Davin. 2009. “Unpacking Sources of Comparative Advantage.” Singapore Management University School of Economics \& Social Sciences Working Paper. Clausing, Kimberly. 2001. "Trade Creation and Trade Diversion in the Canada-United States Free trade Agreement.” Canadian Journal of Economics, 34(3): 677-696.

Coe, David, and Elhanan Helpman. 1995. "International R\&D Spillovers.” European Economic Review, 39(5): 859-887.

Das, Sanghamitra, Mark Roberts, and James Tybout. 2007. "Market Entry Costs, Producer Heterogeneity, and Export Dynamics.” Econometrica, 75(3): 837-873. 
Deardorff, Alan, and Robert Stern. 1990. "Computational Analysis of Global Trading Arrangements.” Ann Arbor: University of Michigan Press.

Debaere, Peter. 2003. "Monopolistic Competition and Trade Revisited: Testing the Mode without Testing for Gravity.” Journal of International Economics, 66(1): 249-66.

Debaere, Peter, and Shalah Mostashari. 2010. "Do Tariffs Matter for the Extensive Margin of Trade? An Empirical Analysis.” Journal of International Economics 81(2): 163-169.

Donaldson, Dave. 2008. "Railroads of the Raj: Estimating the Impact of Transportation Infrastructure.” Mimeograph, London School of Economics.

Dornbusch, Rudiger, Stanley Fischer, and Paul Samuelson. 1977. "Comparative Advantage, Trade, and Payments in a Ricardian Model with a Continuum of Goods.” American Economic Review, 67(5): 823-29.

Eaton, Jonathan, and Samuel Kortum. 2002. "Technology, Geography and Trade.” Econometrica, 70(5): 1741-1780.

Feenstra, Robert. 1998. "Integration of Trade and Disintegration of Production in the Global Economy." Journal of Economic Perspectives, 12(4): 31-50.

Feenstra, Robert, and Gordon Hanson. 1996a. "Foreign Investment, Outsourcing and Relative Wages.” In Political Economy of Trade Policy: Essays in Honor of Jagdish Bhagwati, ed. Robert Feenstra, Gene Grossman, and Douglas Irwing. Cambridge: MIT Press.

Feenstra, Robert, and Gordon Hanson. 1996b. “Globalization, Outsourcing, and Wage Inequality.” American Economic Review, 86(2): 240-245. 
Feenstra, Robert, and Gordon Hanson. 1999. "Productivity Measurement and the Impact of Trade and Technology on Wages: Estimates for the U.S. 1972-1990.” NBER Working Paper 6052.

Feenstra, Robert, and Hiau Looi Kee. 2007. "Trade Liberalization and Export Variety: A Comparison of Mexico and China.” The World Economy, 30(1): 5-21.

Feinberg, Susan, and Michael Keane. 2001. “U.S.-Canada Trade Liberalization and MNC Production Location.” Review of Economics and Statistics, 83(1): 118-132.

Feinberg, Susan, and Michael Keane. 2009. "Tariff Effects on MNC Decisions to Engage in Intra-firm and Arm's-length trade.” Canadian Journal of Economics, 42(3): 900-929.

Findlay, Ronald, and Stanislaw Wellisz. 1982. "Endogenous Tariffs, the Political Economy of Trade Restrictions, and Welfare.” In Import Competition and Response, ed. Ronald Findlay and Stanislaw Wellisz, 223-244. Chicago: University of Chicago Press.

Helpman, Elhanan .1987. "Imperfect Competition and International Trade: Evidence from Fourteen Industrial Countries.” Journal of Japanese and International Economics, 1(1): 62-81.

Helpman, Elhanan, Marc Melitz, and Yona Rubinstein. 2008. "Estimating Trade Flows: Trading Partners and Trading Volumes.” Quarterly Journal of Economics, 123(2): 441-487. 
Heston, A, Summers, R. and Aten, B., 2009. “Penn World Table Version 6.3.” Center for International Comparisons of Production, Income and Prices at the University of Pennsylvania.

Hillman, Arye. 1982. "Declining Industries and Political-Support Protectionist Motives.” American Economic Review, 72(5): 1180-87.

Hillman, Arye. 1989. The Political Economy of Protection.. New York: Harwood.

Hsieh, Chang-Tai, and Keong Woo. 2003. “The Impact of Outsourcing to China on Hong Kong’s Labor Market.” American Economic Review 95(5): 1673-1687.

Hummels, David, Jun Ishii, and Kei-Mu Yi.. 2001. "The Nature and Growth of Vertical Specialization in World Trade.” Journal of International Economics, 54(1): 7596.

Hummels, David, and James Levinsohn. 1995. "Monopolistic Competition and International Trade: Reconsidering the Evidence.” Quarterly Journal of Economics: 110(3): 799-836.

Hummels, Davod, Dana Rapoport, and Kei-Mu Yi. 1998. "Vertical Specialization and the Changing Nature of World Trade.” Fed Reserve Bank New York Economic Policy Reiew, 4, 79-99.

Kehoe, Patrick, and Kehoe, Timothy. 1995. “Capturing NAFTA’s Impact with Applied General Equilibrium Models.” In Modeling North American Integration: Advanced Studies in Theoretical and Applied Econometrics, ed. Patrick Kehoe and Timothy Kehoe, Vol. 31, 17-34. Boston: Kluwer. 
Kehoe, Timothy, and Kim Ruhl. 2003. "How Important is the New Goods Margin in International Trade?” Federal Reserve Bank of Minneapolis Staff Report 324.

Krugman, Paul, amd Anthony Venables. 1995. "Globalization and the Inequality of Nations.” Quarterly Journal of Economics, 110(4): 857-880.

Levchenko, Andrei., 2007. “Institutional Quality and International Trade.” Review of Economic Studies, 74(3): 791-819.

Lileeva, Alla, and Daniel Trefler. 2007. "Improved Access to Foreign Markets Raises Plant-level Productivity ... for Some Plants.” NBER Working Paper number 13297.

Magee, Stephen, William Brock, and Leslie Young. 1989. Black Hole Tariffs and Endogenous Policy Theory: Political Economy in General Equilibrium. New York: Cambridge University Press.

Markusen, James, Venables, A., 1995. "Multinational Firms and the New Trade Theory.” NBER Working Paper 5036.

Markusen, James, and Anthony Venables. 1996a. "The Theory of Endowment, IntraIndustry, and Multinational Trade.” NBER Working Paper 5529.

Markusen, James, and Anthony Venables. 1996b.”Multinational Production Skilled Labor and Real Wages.” NBER Working Paper 5483.

Mayer, Wolfgang. 1984. "Endogenous Tariff Formation.” American Economic Review 74(5): 970-985.

Melitz, Marc. 2003. “The Impact of Trade on Intra-Industry Reallocations and Aggregate Industry Productivity.” Econometrica 71(6), 1695-1725. 
Melitz, Marc, and Gianmarco Ottaviano. 2008. "Market Size, Trade, and Productivity.” Review of Economic Studies, 75(1): 295-316.

Nicita, Alessandro, and Marcelo Olarreaga. 2006. "Trade, Production and Protection 1976-2004.” World Bank Economic Review, 21(1).

Nunn, Nathan. 2007. "Relationship-specificity, incomplete Contracts and the Pattern of Trade.”Quarterly Journal of Economics, 122(2): 569-600.

Ozden, Caglar, and Eric Reinhardt, E., 2005. "The Perversity of Preferences: GSP and Developing Country Trade Policies, 1976-2000.” Journal of Development Economics, 78(1): 1-21.

Romalis, John. 2004. "Factor Proportions and the Structure of Commodity Trade." American Economic Review, 94(1): 67-97.

Romalis, John. 2007. “NAFTA's and CUSFTA's Impact on International Trade.” Review of Economics and Statistics, 89(3): 416-435.

Ruhl, Kim. 2004. “The International Elasticity Puzzle.” NYU Stern School of Business, Working Paper.

Ruhl, K., 2005. "The Elasticity Puzzle in International Economics.” Working Paper, University of Texas at Austin.

Swenson, Deborah. 2004. “Overseas Assembly and Country Sourcing Choices.” NBER Working Paper 10697.

Trefler, Daniel. 1993. "Trade Liberalization and the Theory of Endogenous Protection: An Econometric Study of U.S. Import Policy.” Journal of Political Economy, 101(1): 138-160. 
Whalley, John. 1985. Trade Liberalization among Major World Trading Areas. Cambridge: MIT Press.

Xu, Bin. 2000. "Multinational Enterprises, Technology Diffusion, and Host Country Productivity Growth.” Journal of Development Economics, 62(2): 477-493.

Xu, Bin, and Jianmao Wang, J., 1999. "Capital Goods Trade and R\&D Spillovers in the OECD.” Canadian Journal of Economics, 32(5):1258-1274.

Yamada, Tetsuo. 2005. "Relevance and Applicability of the UNIDO Industrial Statistics Database for Research Purposes.” United Nations Department of Statistics and Social Affairs Working Paper ESA/STAT/AC.105/21.

Yi, Kei-Mu. 2003. "Can Vertical Specialization Explain the Growth of World Trade?” Journal of Political Economy, 111(1): 52-102.

Yi, Kei-Mu. 2010. “Can Multi-stage Production Explain the Home Bias in Trade?” American Economic Review, 100(1): 364-393. 